\title{
Traditional Ratios vs. Cash Flow based Ratios: Which One is Better Performance Indicator?
}

\author{
Suborna Barua ${ }^{1}$, Anup Kumar Saha ${ }^{2, *}$ \\ ${ }^{1}$ Department of International Business, University of Dhaka, Bangladesh \\ ${ }^{2}$ Department of Accounting \& Information Systems, Jagannath University, Bangladesh
}

Copyright (C) 2015 by authors, all rights reserved. Authors agree that this article remains permanently open access under the terms of the Creative Commons Attribution License 4.0 International License

\begin{abstract}
Cash flow prediction is involved in a number of economic decisions, particularly in investment. Previous researches conducted in the United States have provided inconsistency in the results of investigating accounting data, cash flow and accrual accounting data in predicting future cash flows. No published research has studied cash flow prediction in Bangladesh. The current study investigates the ability of accrual and cash flows accounting information to predict future cash flows of Bangladeshi listed companies. This study analyses Balance sheet, Income Statement and Cash Flow statement. In addition, cash flow ratios and Income statement based ratios are calculated in order to get the same pattern of result and to make comparisons. Data used in this study are collected from the financial statements of non-manufacturing companies listed on the Stock Exchange of Bangladesh from 2001 to 2010. Cash flow data are selected directly from the cash flow statements. Empirical results show that cash flow and accrual component of earnings can be used to predict future cash flows of Bangladeshi listed companies and cash flows have better predictive power than traditional based ratios. However, the results indicate that cash flow ratios are sometimes providing the better and accurate picture of the companies. In addition, this study finds that our economic crises as well as abnormal condition of our stock market are caused due to the manipulation of accounting data for consecutive financial year.
\end{abstract}

Keywords Cash Flow from Operations, Dhaka Stock Exchange, Long Term Assets, Long Term Liabilities

JEL Code: G12, G310.

\section{Introduction}

Cash flow information assists its financial statement users in obtaining the relevant information concerning the use and source of virtually the entire financial resources over a given time period. Traditionally, financial analysis, for a long time, depended on accounting performance via profitability measures such as return on assets and net sales to income, among others. These forms of ratios, however, are affected by the fundamental drawbacks that are characteristics of 'accrual based accounting'. Most computed ratios usually focus only on balance sheets and income statements. This is unfortunate since the statement of cash flows (SCF) can also offer useful insights from ratio analysis. Balance sheet ratios can only provide a date-in-time perspective, whereas the SCF represents activity for a continuous period. Income statements report the results of operations for a period of time, but do not disclose other important changes in resources that result from activities in financing and investing. The SCF complements the balance sheet and income statement by providing additional information concerning an organization's ability to operate efficiently, to finance growth, and to pay its obligations. The purpose of this study is to provide an overview of cash flow ratios as a powerful and effective analytical tool.

\section{Objectives}

The primary objective is to establish the usefulness of the cash flow based ratios in today's competitive business world. Cash flow information could also be useful in complementing the information already provided by accrual accounting. The usefulness of cash flow information also includes its ability to generate cash flows from internal sources, to service obligation from internal cash flows and to rely on outside financing.

The second objective is to investigate some cash flow ratios suggested by many authors, like Beaver [1], Lee [8], Dambolena and Shulman [6], Sharma and Iselin [10], Stanko and Zeller [11] and Mills and Yamamura [9].

The third objective is to suggest a list of cash flow ratios to be included in a financial analysis. Financial statements for ten years have been evaluated by means of suggested cash flow ratios. 


\section{Literature Review}

Beaver [1] reported that cash flow from operations (CFFO), proxied by net income plus depreciation, depletion and amortisation, to total debt had the lowest misclassification error relative to common accrual measures of financial health. However, his univariate approach to analysing financial distress was seldom followed because while one ratio would indicate failure another could indicate non-failure.

Like Beaver [1], Deakin [5] defined cash flow as net income plus depreciation, depletion and amortisation. While Blum [2] have shown that cash flow information contains information content in predicting corporate bankruptcy, they are not frequently cited. The rare citation is probably due to the measure of cash flow employed by these researchers. These researchers used Beaver's [1] definition of CFFO.

Lee [7], a strong advocate of cash flow reporting, showed that the fall of Laker Airways was foreseeable on a cash flow basis. His analysis of CFFO revealed that Laker Airways was in financial trouble three years prior to failure while profits were increasing as failure approached. A stream of multivariate modelling studies began investigating the information content of this refined measure of CFFO. Using an estimation sample and a validation sample comprising 60 bankrupt and 230 non-bankrupt firms and three measures of cash flow information, viz. CFFO, CFFO/Current Liabilities and CFFO/Total Liabilities, Casey and Bartczak [4][5] concluded that none of the three operating cash flow variables significantly improved the classification accuracy of the six accrual ratios model. Casey and Bartczak [5] reached this conclusion on the basis of the number of firms correctly classified into their respective groups. While their conclusion is valid, there are grounds to argue that cash flow information has significant information content over accrual information in assessing the predicted probability of failure. Predicting the probability of failure extends the mere classification into either the failed or nonfailed group and is practically more useful. For instance, the classification of a company into a non-failed group does not provide information on the likelihood of this group membership. Perhaps the likelihood of the membership into this group is $51 \%$. Knowing the probability of failure enables the assessment of the degree of distress and the risk associated with a particular company. Bankers may lend at premium interest rates to companies that are classified in the failed group that have a marginal probability of failure. Furthermore, bankers usually assess credit risk, which is a continuous measure, of a loan applicant rather than merely classifying the applicant into a dichotomy of risky versus non-risky.

\section{Methodology}

This study aims to investigate the abilities of cash flow ratios to predict the actual picture of the company. Even though there is no empirical evidence supporting these ratios, this study initiated these ratios as accurate and superior substitute of traditional (income statement based) ratios.

Fifteen traditional ratios are substituted by fifteen cash flow based ratios, which are as follows:

Table 1. Traditional Ratios

\begin{tabular}{|c|c|c|}
\hline & Liquidity Ratio: & \\
\hline 1 & Current Ratio $=$ & Current Assets / Current Liabilities \\
\hline \multirow[t]{2}{*}{2} & Quick Ratio= & (Current Assets - Inventory) / Current Liabilities \\
\hline & Asset Management Ratio: & \\
\hline 3 & Fixed Assets Turnover $=$ & Turnover / Net Fixed Assets \\
\hline \multirow[t]{2}{*}{4} & Total Assets Turnover $=$ & Turnover / Total Assets \\
\hline & Debt Management Ratio: & \\
\hline 5 & Debt to Assets= & Total Debt / Total Assets \\
\hline 6 & Interest Coverage $=$ & EBIT / Interest \\
\hline \multirow[t]{2}{*}{7} & Fixed Charge Coverage $=$ & Earning before Interest and Lease / Interest, Lease, Debt payment and Preference dividend \\
\hline & Profitability Ratio: & \\
\hline 8 & Return on Sales $=$ & Net Income / Turnover \\
\hline 9 & Return on Assets $=$ & Net Income / Total Assets \\
\hline 10 & Return on Equity= & Net Income / Shareholders' Equity \\
\hline \multirow[t]{2}{*}{11} & Return on Capital Employed= & Earnings / Equity and Long Term Debt \\
\hline & Sufficiency Ratio: & \\
\hline 12 & Debt Coverage $=$ & Total Debt / Net Income \\
\hline 13 & Repayment of Borrowing $=$ & Repayment of Borrowing / Net Income \\
\hline 14 & Dividend Payout $=$ & Dividend paid / Net Income \\
\hline 15 & $\begin{array}{l}\text { Capital Investment per Tk of } \\
\text { Funds= }\end{array}$ & Capital Investment / Total Sources of Funds \\
\hline
\end{tabular}

*** Repayment of Borrowing $=$ Past LTL -Present LTL

*** Capital Investment $=$ Past LTA - Present LTA 
Table 2. Cash Flow Based Ratios

\begin{tabular}{|c|c|c|}
\hline & Liquidity Ratio: & \\
\hline 1 & Cash to Short Term Debt $=$ & CFFO / Short Term Debt \\
\hline \multirow[t]{2}{*}{2} & Critical Needs Coverage $=$ & $(\mathrm{CFFO}+$ Interest paid $) /($ Interest paid + Current Debt + Dividend $)$ \\
\hline & Asset Management Ratio: & \\
\hline 3 & Cash to Fixed Assets $=$ & CFFO / Fixed Assets \\
\hline \multirow[t]{2}{*}{4} & Reinvestment $=$ & CFFO / Capital Invested \\
\hline & Debt Management Ratio: & \\
\hline 5 & Cash to Debt $=$ & CFFO / Total Debt \\
\hline 6 & Cash Interest Coverage $=$ & CFFO / Interest Paid \\
\hline \multirow[t]{2}{*}{7} & Cash Fixed Charge Coverage $=$ & CFFO / Interest, Lease, Debt payment and Preference dividend \\
\hline & Profitability Ratio: & \\
\hline 8 & Cash to Sales $=$ & CFFO / Turnover \\
\hline 9 & Cash to Assets $=$ & CFFO / Total Assets \\
\hline 10 & Cash to Equity $=$ & CFFO / Shareholders' Equity \\
\hline \multirow[t]{2}{*}{11} & Cash to Equity Employed= & CFFO / Equity and Long Term Debt \\
\hline & Sufficiency Ratio: & \\
\hline 12 & Debt Coverage $=$ & Total Debt / CFFO \\
\hline 13 & Repayment of Borrowing $=$ & Repayment of Borrowing / CFFO \\
\hline 14 & Dividend Payout $=$ & Dividend paid / CFFO \\
\hline 15 & Capital Investment per Tk of Funds $=$ & Cash Paid for Investment / Total Sources of Funds \\
\hline
\end{tabular}

*** $\mathrm{CFFO}=$ Cash Flow from Operation

*** Capital Invested $=$ Acquisition of PPE, Building, Land etc.

*** Repayment of Borrowing $=$ Long term Loan paid

Table 3. Sample Selection for Research on Cash Flow Vs Income based Ratios

\begin{tabular}{|c|c|c|c|c|}
\hline Serial & Name of the Industry & No. of Company & $\begin{array}{c}\text { \% } \\
\text { (out of total 95) }\end{array}$ & No. of Sample Company \\
\hline 1 & Bank & 30 & $32 \%$ & 8 \\
\hline 2 & Financial Institutions & 21 & $22 \%$ & 4 \\
\hline 3 & Insurance & 44 & $46 \%$ & 10 \\
\hline & Total $=$ & 95 & $100 \%$ & 22 \\
\hline
\end{tabular}

Table 4. List of Companies

\begin{tabular}{ccc}
\hline Banks & Insurances & Financial Institutions \\
\hline AB Bank Ltd & Eastern Insurance & ICB \\
Dhaka Bank Ltd & Janata Insurance & IDLC Finance Ltd \\
Eastern Bank Ltd & Karnaphuli Insurance & United Leasing \\
Islami Bank Ltd & National Life Insurance & Uttara Finance \\
Prime Bank Ltd & Peoples Insurance & \\
Pubali Bank Ltd & Prime Insurance & \\
South East Bank Ltd & Reliance Insurance & \\
United Commercial Bank Ltd & Ruplai Insurance & United Insurance \\
\hline
\end{tabular}


This study recommends the rarely used ratios, which have not been applied in Bangladesh yet but some other countries like Kenya, South Africa, and Thailand etc. have revealed with this concern in small structure. Here focus is to identify the foremost differences between traditional (income statement based) and cash flow based ratios. By the following equation, differences in percentages against traditional ratios have been made:

\section{Difference $(\%)=$ \\ (Traditional Ratio Value -Cash Flow based Ratio Value) Traditional Ratio Value}

Finally, this study will help to identify the financial fraudulent which may occur due to the accrual basis of accounting.

\subsection{Data Sources}

Data are collected from financial statements of companies listed. To focus on the statements of cash flows, cash flows from operation activities are selected directly from the cash flow statements. Earnings are derived from income statements. Total assets, sales and other variables are selected from balance sheets and income statements.

\subsection{Company Selection Based on Industry Percentage}

The sample used for this research comprises with non-manufacturing companies listed on Dhaka Stock Exchange. The samples have satisfied following criteria:

- The companies must have complete data for all variables such as cash flow statements, income statements and balance sheets.

- The companies must be enlisted in DSE before the year of 2000 .

\section{Why Cash Flow is Better Measurement than Income Statement?}

The advantage of cash flow statement is that it provides information that enables users to evaluate the change in the net assets, its financial structure (like liquidity and solvency) and its ability to affect the amounts and timing of cash flow in order to change the circumstances and opportunities. Sometimes due to accrual basis of accounting a company may have satisfactory net income but one and only cash flow statement can tell us how many cash is generated from this sales and other operation. If most of the sales are on credit then it means a risk is associated with this. So any decision based on only income statement can sometimes be overestimated or underestimated. If cash flow information is useful but unused, the logical conclusion is that the analysts are not analyzing available data properly. While there is no general consensus on appropriate cash flow ratios, this study will explore the relative utility of newly derived cash flow ratios in financial analysis and will determine if the potential exists to predict financial failure.

An examination was made of the usefulness of the cash flow statement and a brief review was given of the importance of cash flow ratios for financial analysis. The main focus of the cash flow statement is to determine whether an entity can generate positive cash flows from its normal operations. However, this does not provide a full assessment of the liquidity and viability of an entity. The cash flow statement must be related to other figures in the financial statement to arrive at an adequate picture of the cash generating ability of an entity. Ratio analysis is a useful and efficient tool for analyzing financial information. To date, neither text writers nor analysis have developed ratios for effective evaluation of the cash flow statement. Such ratios, used in conjunction with traditional balance sheet and income statement ratios, should lead to a better understanding of the financial strengths and weaknesses of an entity.

\section{Indicator of Performance Analysis}

\subsection{Liquidity Ratio}

Current Ratio Vs Cash to Short term Debt Ratio: Traditional Current assets consist of some assets (like account receivable, inventories) which are not actually as liquid as Cash. So, they may fail to meet up the current liabilities, where the recommended "Cash to Short Term Debt ratio" shows the genuine liquidity position of a firm. 


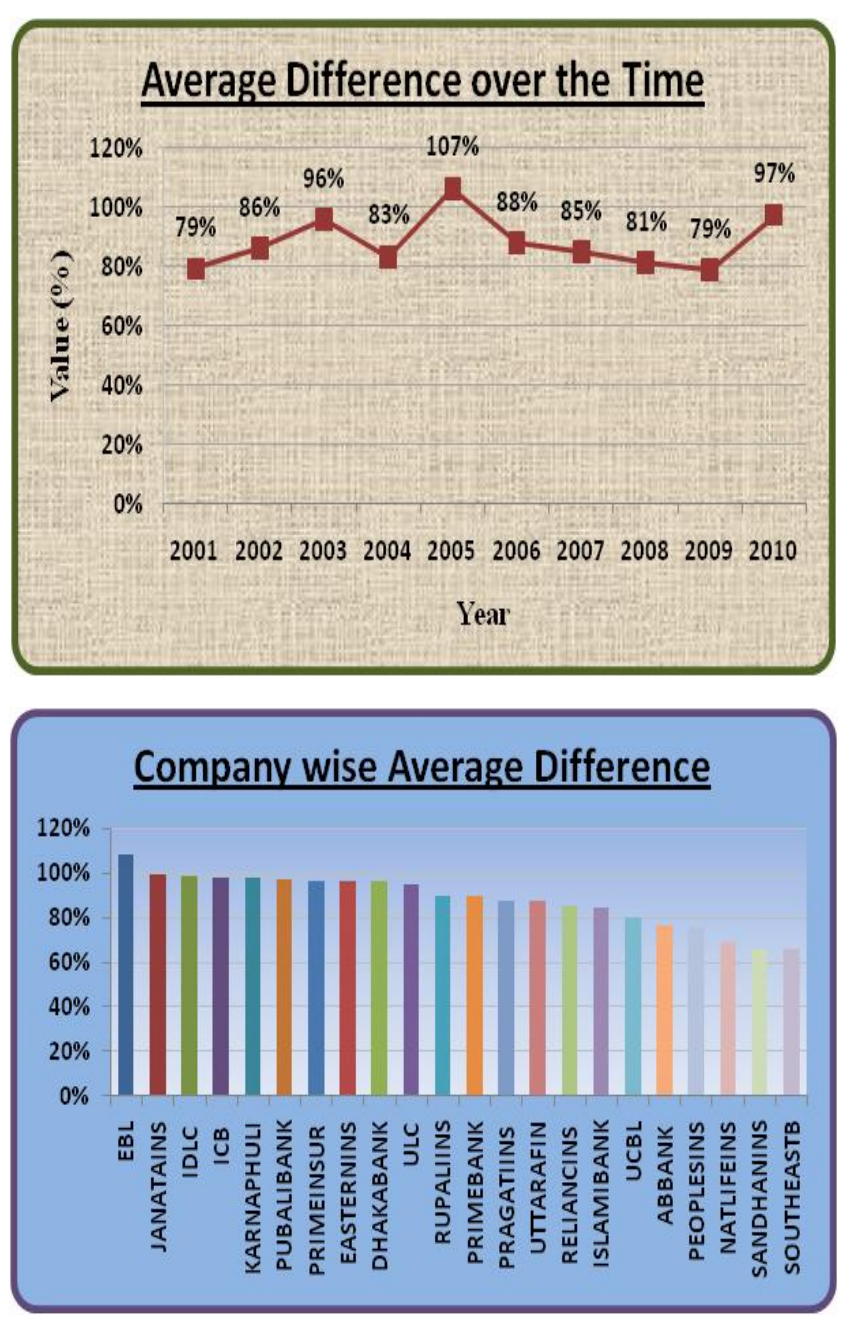

Figure 1. Current Ratio vs Cash to Debt Ration Average Difference over Time and Company-wise

Explanation: Traditional current ratio overestimates the liquidity health of a firm by more than $78 \%$ over the year. In the analysis, it was found that in 2005 the overestimation was $107 \%$ that is the highest so far. On the other hand, if we concentrate on individual company wise average difference then it is clear that EBL is on the top where it has $108 \%$ deviation and the SOUTHEASTB comparatively deviates in a low volume that is $66 \%$ [Appendix 01 ].

Significance to Decision Making: This huge overestimation of liquidity position sometimes misleads the creditors and other relevant users. Due to the accrual basis of accounting, company may manipulate its current assets and current liabilities. So it will be a wise decision to consider the Cash Flow from Operations (CFFO).

Quick Ratio Vs Critical Needs Coverage: Traditional quick ratio is a better liquidity indicator then traditional current ratio because it excludes the inventory. But critical needs coverage is much more focused than this because it considers only three expenditures (interest paid, current debt, and dividend) that must be repaid within 12 months by the CFFO.

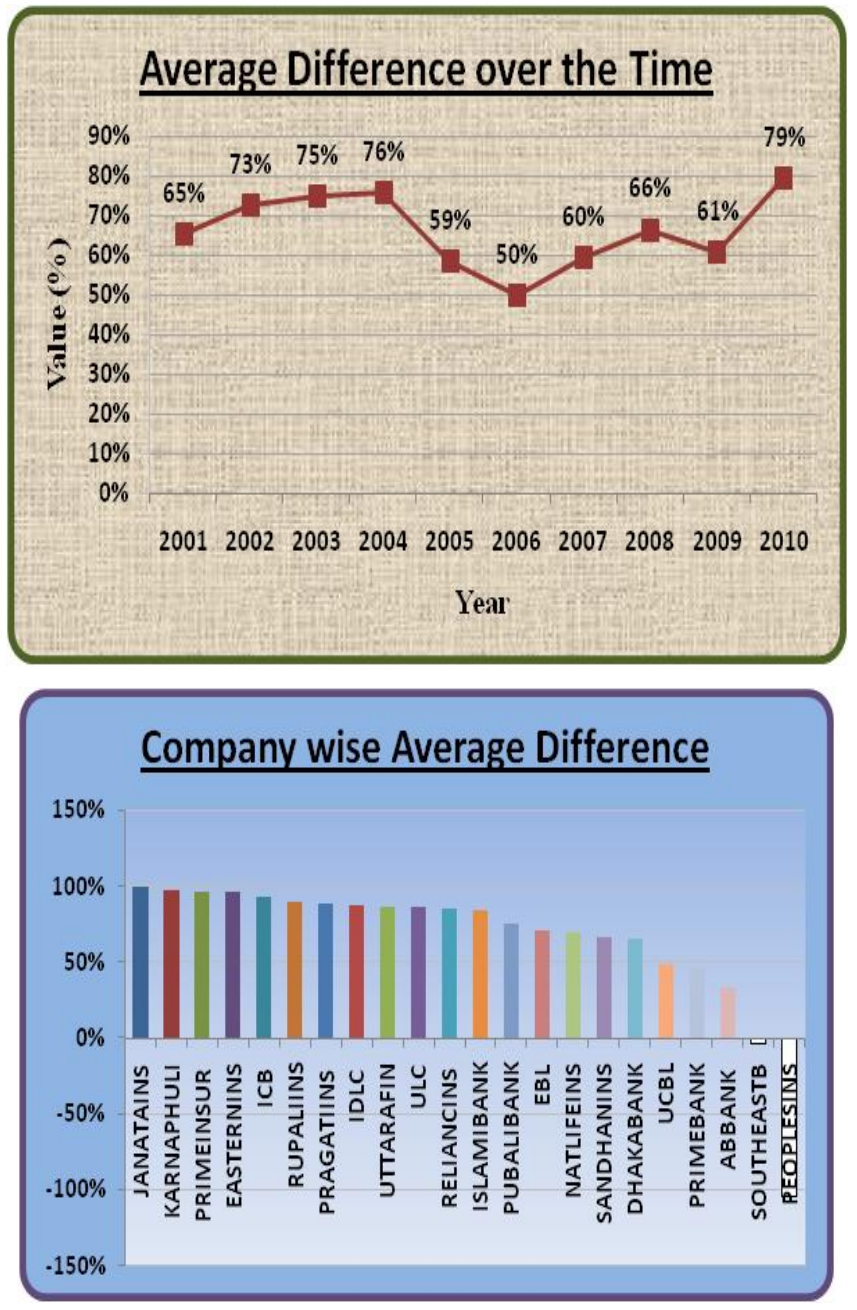

Figure 2. Quick Ratio vs Critical Needs Coverage Average Difference over Time and Company-wise

Explanation: On an average, the quick ratio overestimates the liquidity position of a firm by more than $50 \%$. The highest difference was found in 2010 , where it was $79 \%$. At the same time, company wise average difference show that JANATAINS is on the top that holds $99 \%$ deviation [Appendix 02].

Significance to Decision Making: Like current ratio, quick ratio also misinforms their liquidity position to their users as well as stakeholders. So, they can rely on critical needs coverage ratio to identify the actual liquidity health of a company.

\subsection{Asset Management Ratio}

Fixed Assets Turnover Vs Cash to Fixed Assets: Fixed asset turnover indicates how well the business is using its fixed assets to generate sales. However, managers sometimes manipulate the sales in order to increase the fixed asset turnover. To identify the absolute use of fixed asset, we should compare it against CFFO rather turnover. 


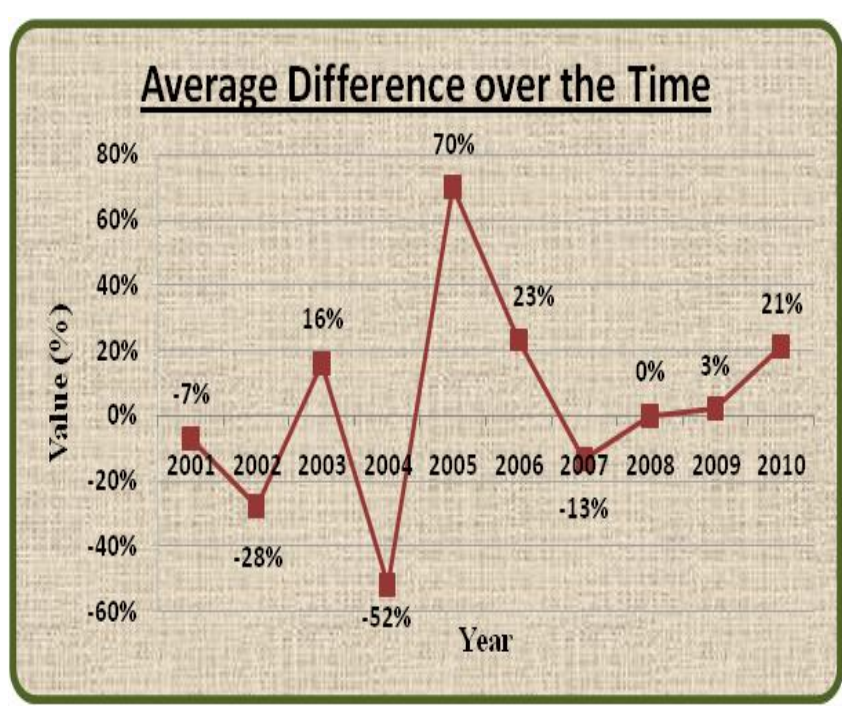

\section{Company wise Average Difference}

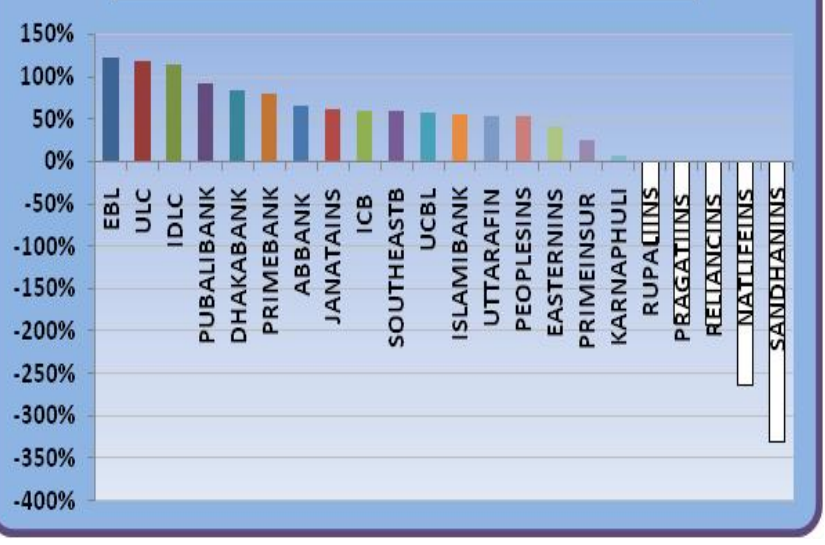

Figure 3. Fixed Assets Turnover vs Cash to Fixed Assets Average Difference over Time and Company-wise

Explanation: The graph shows that there is mixed trend of differences between traditional and cash flow based ratios throughout the year. But in 2004, they are underestimating by $-52 \%$ and in 2005 overestimating by $70 \%$. Only in 2008 there is no variation between two forms of ratios. At the same time, company wise average difference shows that EBL is on the top that holds $123 \%$ variation and SANDHAINS is at low rank with -331\% [Appendix 03].

Significance to Decision Making: To measure the performance of the asset, generally it will not be sensible decision to depend on traditional ratio rather cash to fixed asset ratio represent the final picture of assets as it can be compared with cash.

Total Assets Turnover Vs Reinvestment: Assets turnover measures the efficiency of a company's use of its assets in generating sales revenue or sales income to the company. On the other hand, reinvest ratio shows the portion of CFFO that has been invested for fixed assets.

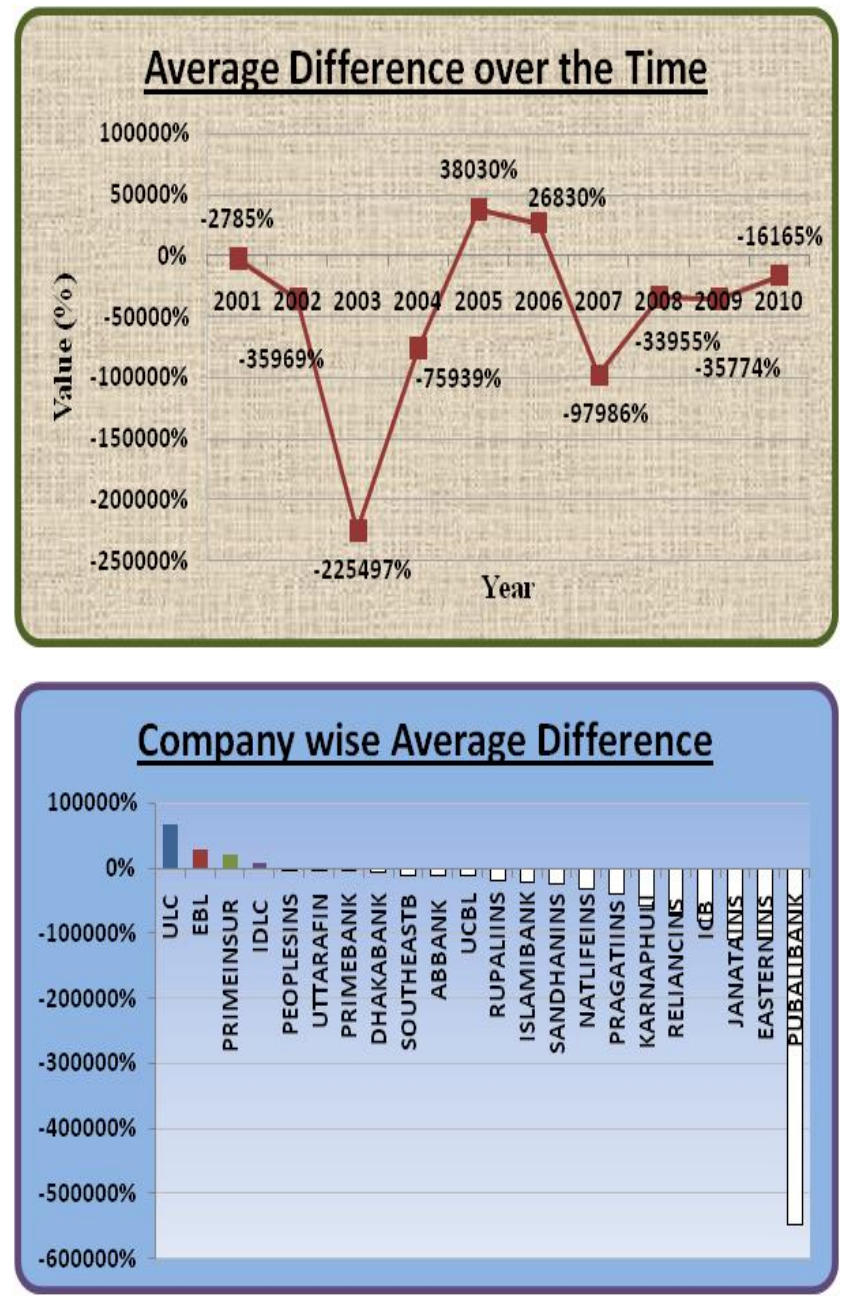

Figure 4. Total Assets Turnover vs Reinvestment Average Difference over Time and Company-wise

Explanation: Again this graph shows that there is diverse trend of differences between traditional and cash flow based ratios throughout the year. They are not following any consistent movement. In 2003 the difference was $-225497 \%$ that means it underestimates the assets' performance and gradually they are improving their position. However, in 2005 suddenly traditional ratio overstates by $38030 \%$, which is actually abnormal. On the other hand, company wise difference, ULC took the pick position and PUBALIBANK is at the down position with -548682\% [Appendix 04].

Significance to Decision Making: Total assets turnover is an important investment indicator. So, accurate information may help the investors about their investing decision.

\subsection{Debt Management Ratio}

Debt to Assets Vs Cash to Debt: This traditional ratio shows the percentage of total assets that are financed by debt. On the other hand, cash to debt means percentage of total cash against the debt. 


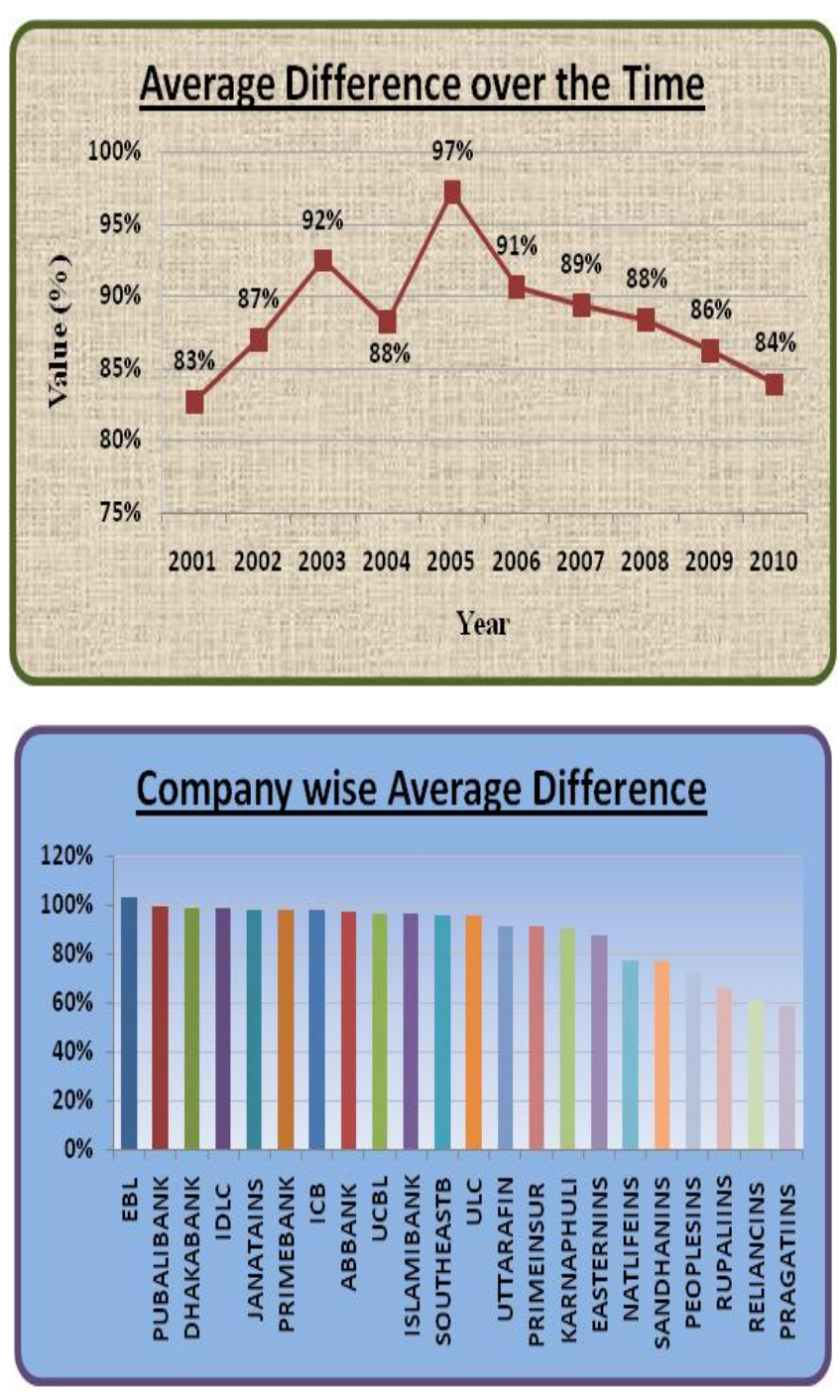

Figure 5. Debt Assets vs Cash to Debt Average Difference over Time and Company-wise

Explanation: By the following graph, it can be concluded that in case of yearly wise average difference the companies are overestimating by more than $82 \%$. At the same time, company wise average difference shows that EBL is on the top that holds $103 \%$ variation and PRAGATIINS is at low rank with 58\% [Appendix 05].

Significance to Decision Making: More cash against debt increase the probability of debt repayment as well as reduce the risk of lender. As a result, sometimes, cost of debt may be reduced. So, parties should use Cash to Debt which is more meaningful rather Debt to Assets.

Interest Coverage Vs Cash Interest Coverage: The traditional interest coverage ratio measures a company's ability to meet its interest obligation by its EBIT. Earning always does not generate the ability to pay its interest whether cash coverage ratio shows the relationship between CFFO and interest.

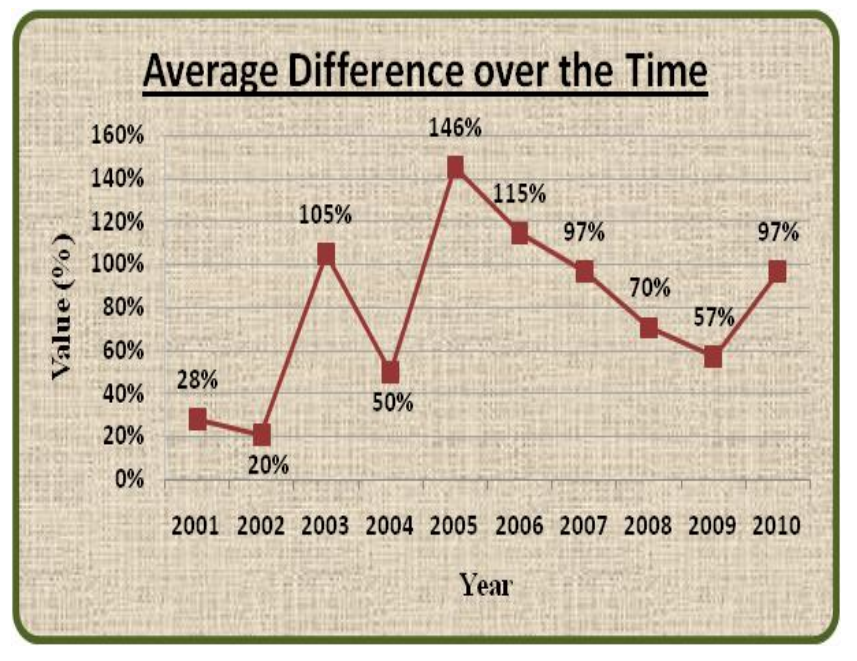

\section{Company wise Average Difference}

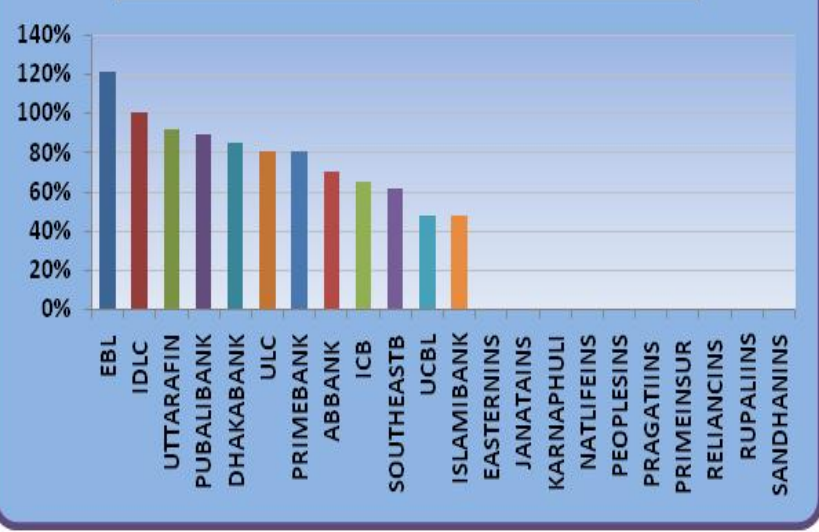

Figure 6. Interest Coverage Vs Cash Interest Coverage Average Difference over Time and Company-wise

Explanation: In the yearly wise average difference analysis, it is seen that from 2001 to 2004 the companies are overestimating but in inconsistent way. After 2005 to 2009, they are maintaining a consistent way of overestimation. On the other hand, EBL has the highest difference with $121 \%$ and the ISLAMIBANK is at the below position with $48 \%$ [Appendix 06].

Significance to Decision Making: High interest coverage ratio cannot ensure the creditors about the ability of a firm to repay its interest rather cash interest coverage surely can inform regarding the repayment position of a firm. Therefore, it is a better indicator.

\subsection{Profitability Ratio}

Fixed Charge Coverage Vs Cash Fixed Charge Coverage: Fixed charge coverage indicates a firm's capacity to pay off its yearly fixed charge. However, problem arises when we only focus on earnings before interest and lease rather CFFO. To resolve the crisis we can centre on cash fixed charge coverage as it measure fixed charge against CFFO. 

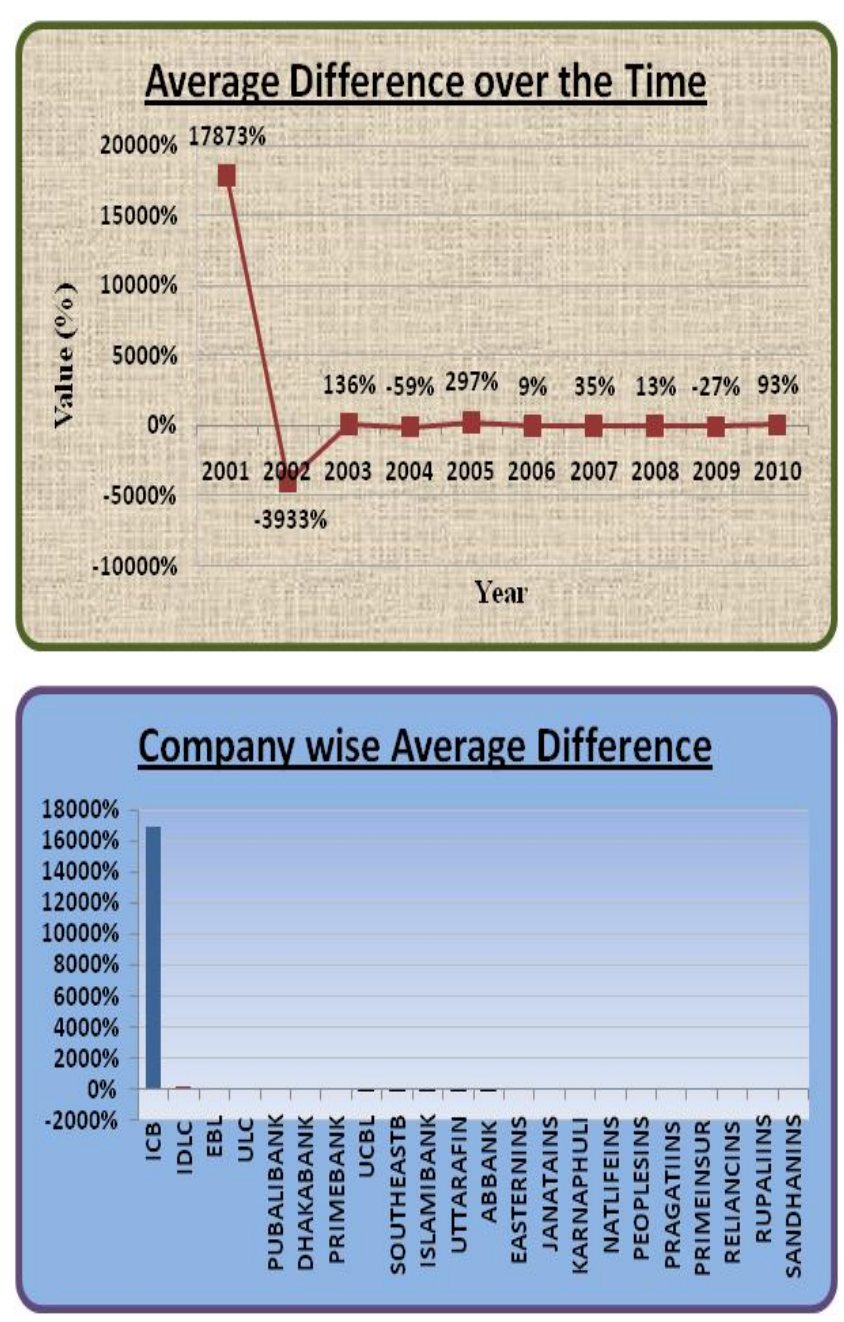

Figure 7. Fixed Charge Coverage Vs Cash Fixed Charge Coverage Average Difference over Time and Company-wise

Explanation: From the following graph, it is clearly observable that in 2001 companies are highly overstating with $17873 \%$. After that their overestimation state are decreasing in a consistent way. On the other hand, in case of company wise average difference only ICB is highly overestimating status [Appendix 07].

Significance to Decision Making: After paying fixed charges, a company goes for earning its profit. On the other hand, timely fixed charge payments smooth its way of further collection of fund.

Return on Sales Vs Cash to Sales: Return on sales show the amount of revenue is coming from sales. But we should keep in mind that sales means both accrual and cash sales. So if most of the sales are on credit that cannot be a good performance indicator though returns on sales give a higher percentage.
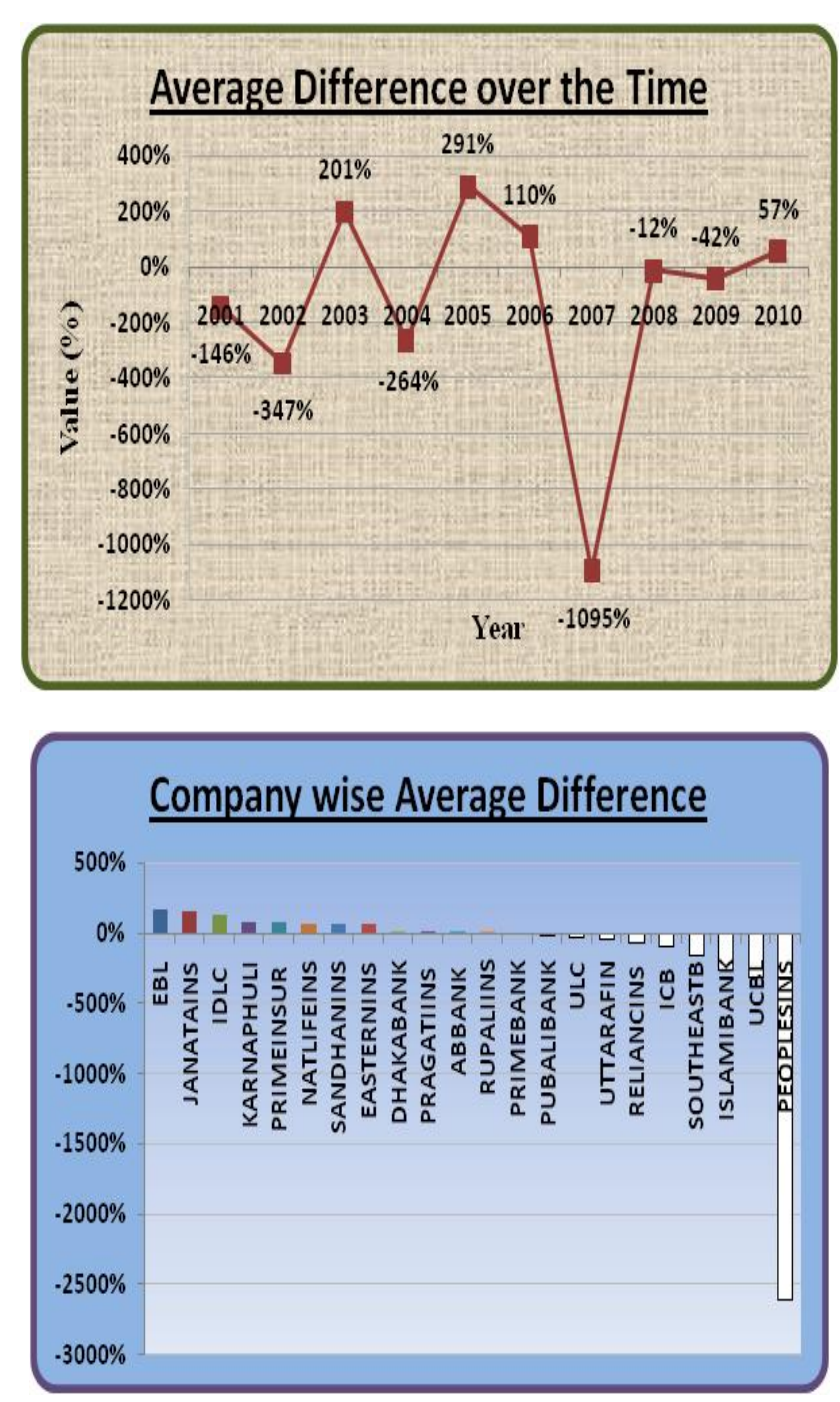

Figure 8. Return on Sales vs Cash to Sales Average Difference over Time and Company-wise

Explanation: In this study, there is a huge underestimation in 2007 in case of yearly average difference. At the same time, PEOPLESINS individually understates the value in a wide range [Appendix 08].

Significance to Decision Making: So to take the right decision regarding sales we should observe how much sales are happening on cash, because cash is always a powerful weapon for every company.

Return on Assets Vs Cash to Assets: Return on assets percentage shows how profitable a company's assets are in generating revenue. Instead of this ratio we should focus how much CFFO is generating from its assets that means Cash to Assets. 

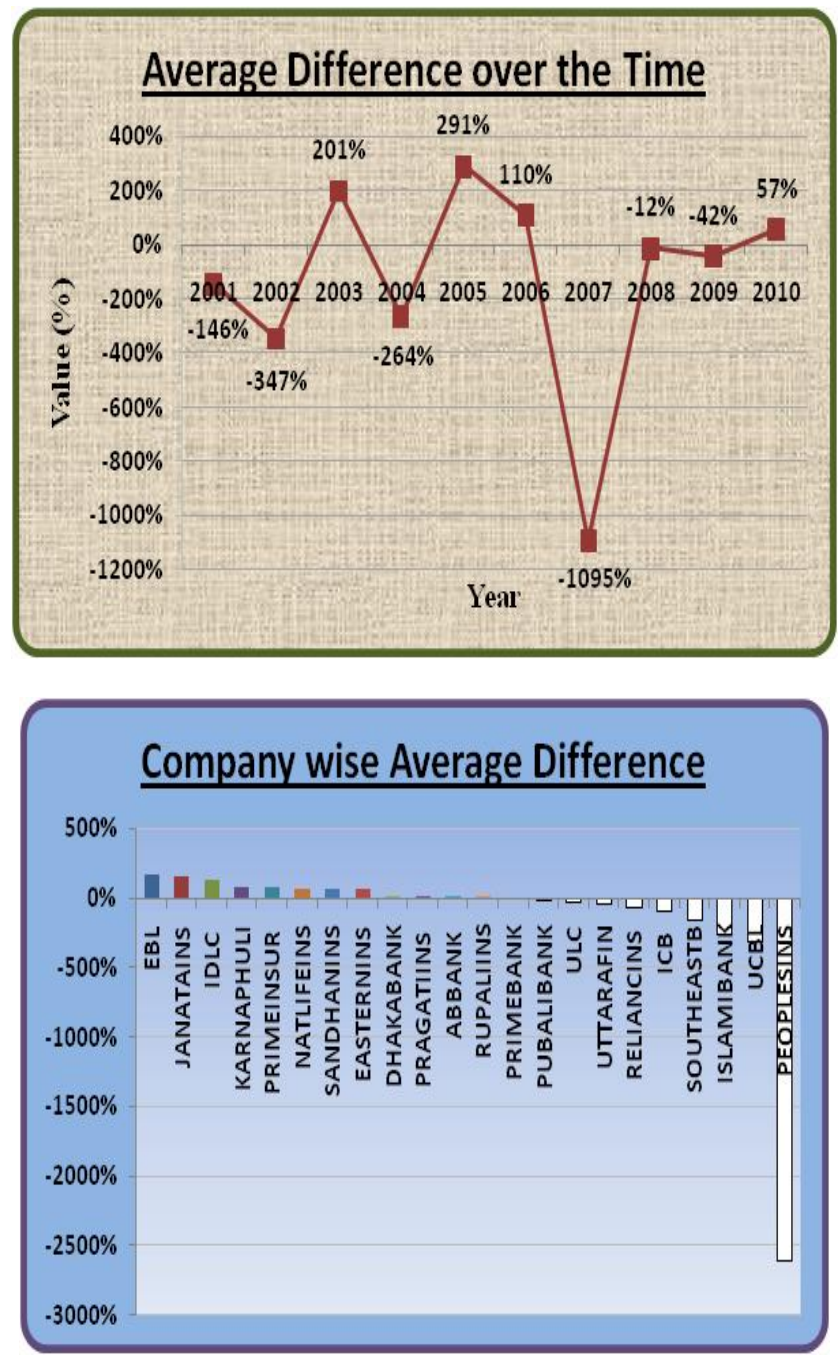

Figure 9. Return on Assets vs Cash to Assets Average Difference over Time and Company-wise

Explanation: Unfortunately, this study tells that on yearly average ROA underestimates the actual assets' performance. This underestimation is higher in the year of 2007. On the other hand, in case of company wise average difference, again PEOPLESINS is on the below of underestimation that is $-2609 \%$ [Appendix 09].

Significance to Decision Making: So to measure the accurate performance of assets, we should notice its Cash generating capacity not revenue generating capacity.

Return on Equity Vs Cash to Equity: Return on equity percentage shows how much profit a company can earn by its equity. Where we should measure how much cash is generating from its equity. Because accrued accounting is always associated with a particular risk.
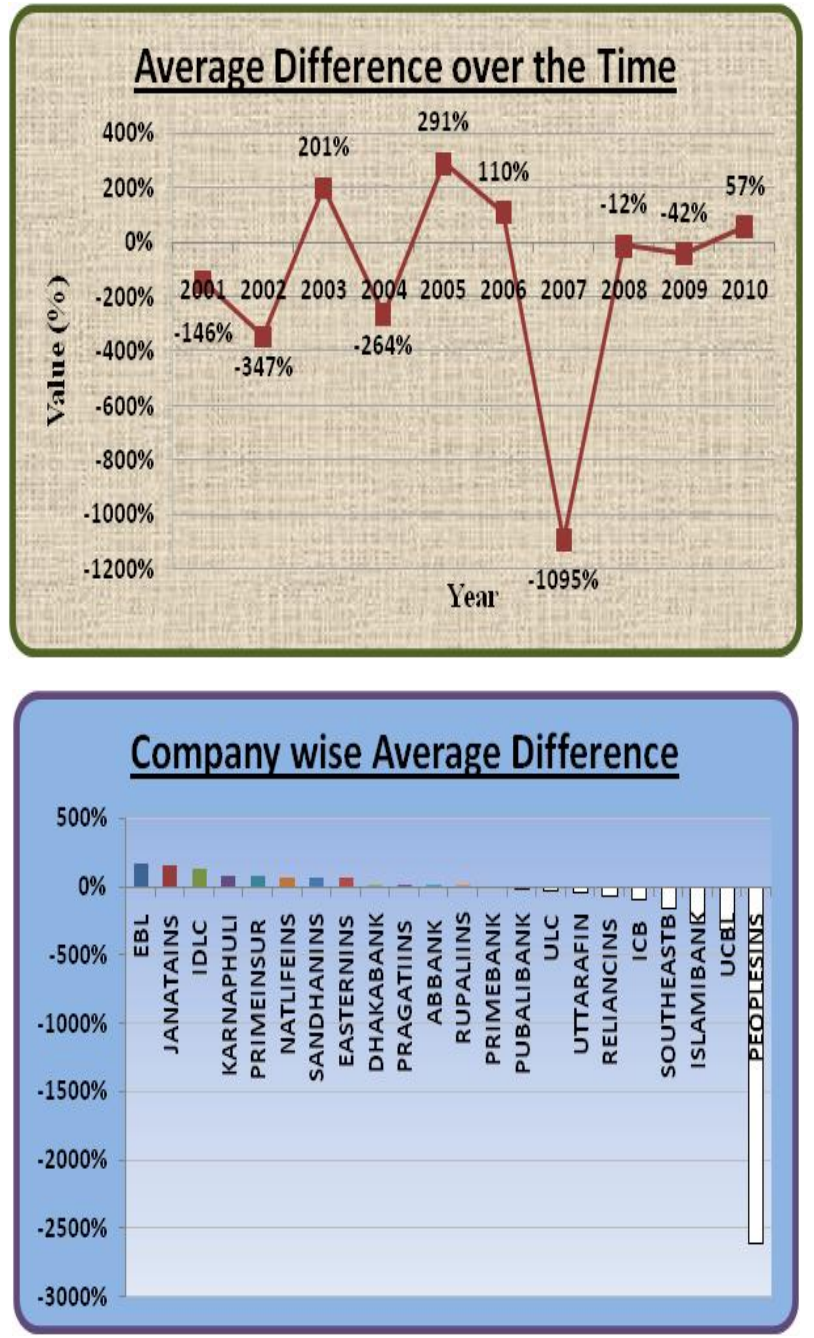

Figure 10. Return on Equity vs Cash to Equity Average Difference over Time and Company-wise

Explanation: In the graph of average difference over the time shows that there is a mixed trend of differences. Where sometimes it overstates and sometimes understates the actual picture. But in 2007 it underestimates deeply. Individually EBL on an average overstate by $165 \%$. On the other hand, PEOPLESINS highly understates it by $2609 \%$ [Appendix 10].

Significance to Decision Making: To get the actual return from equity, it must be measured against cash generation.

Return on Capital Employed Vs Cash to Equity Employed: Return on capital employed demonstrates the revenue are generating from capital employed where our cash flow based ratio explain the cash generating capacity of equity. 


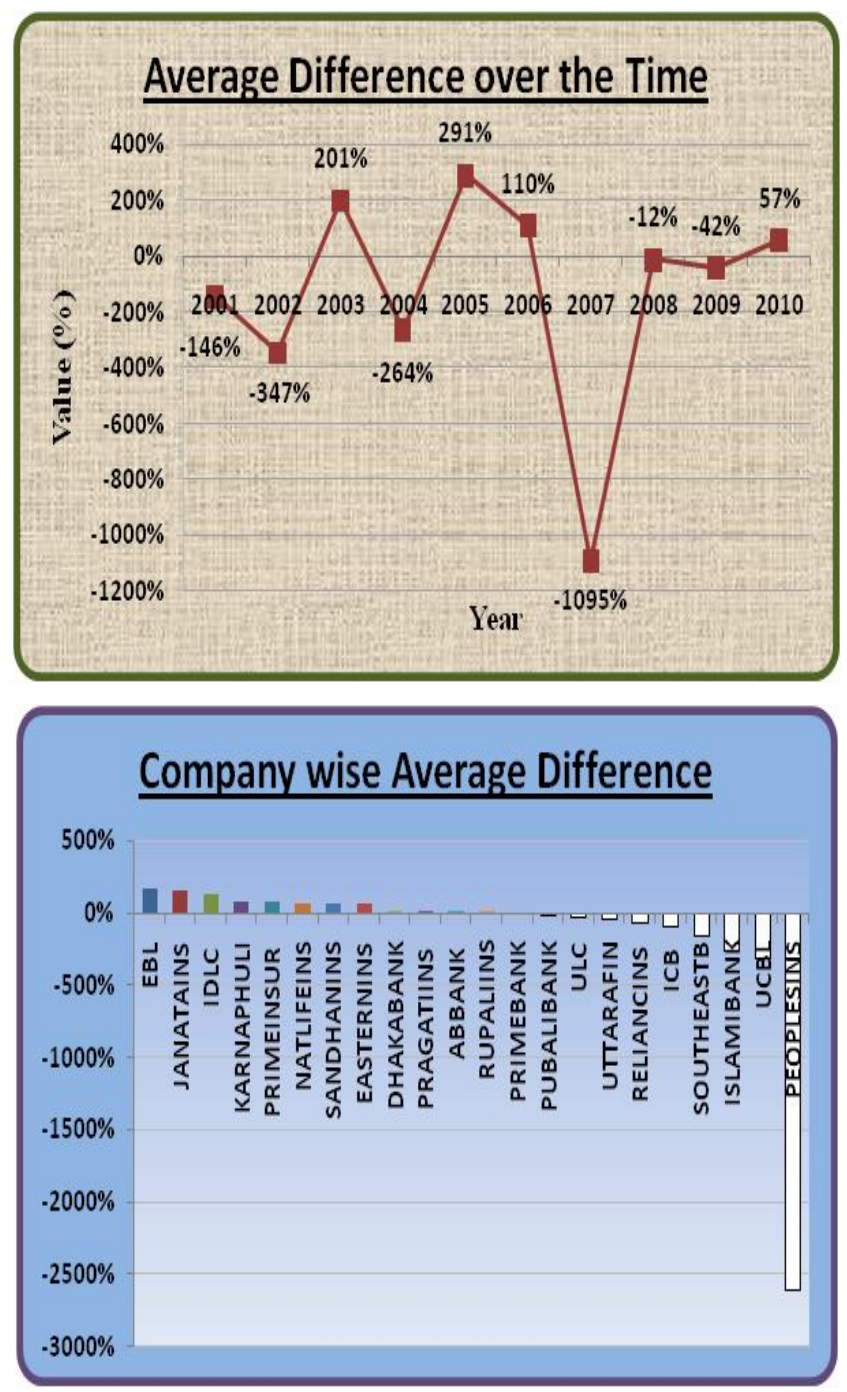

Figure 11. Return on Capital Employed vs Cash to Equity Employed Average Difference over Time and Company-wise

Explanation: According to this graph, again, there is diverse movement of yearly average differences but in 2007 it underestimates deeply by $1095 \%$. On the other hand, in case of company wise average differences again PEOPLESINS understates the difference [Appendix 11].

Significance to Decision Making: By the traditional ratio investors can get wrong information about their equity investment.

\subsection{Sufficiency Ratio}

Traditional Vs Cash Flow based Debt Coverage: Traditional debt coverage ratio measures company's ability to repay its total debt by its net income. On the other hand, special cash flow based debt coverage ratio shows the same repayment ability of total debt by CFFO.
Explanation: Most of the time traditional ratios understate the real scenario. And that was highest in 2007 at $195 \%$. At the same time, PRAGATIINS individually understates by $498 \%$ [Appendix 13].

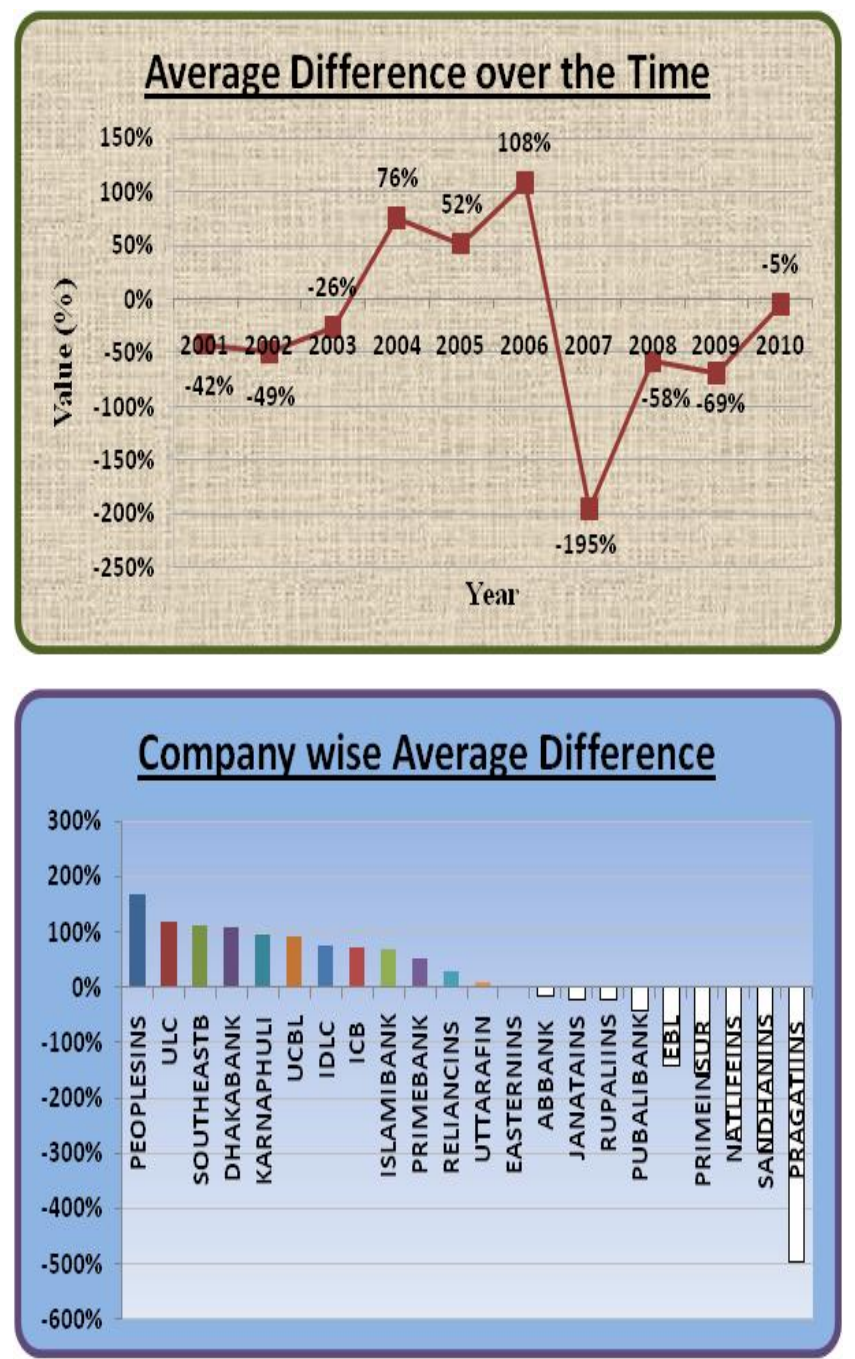

Figure 12. Traditional Vs Cash Flow based Debt Coverage Average Difference over Time and Company-wise

Significance to Decision Making: Debt coverage helps to predict the probability of bankruptcy. So, as much as accurate information collection is possible, the prediction will be more realistic and meaningful.

Repayment of Borrowing Net Income Vs Operating Cash Flow: Repayment of borrowing against NI and against CFFO, demonstrate two things. However, we should always emphasis a firm's ability of repaying its long term borrowing from its current year operating cash flow. 


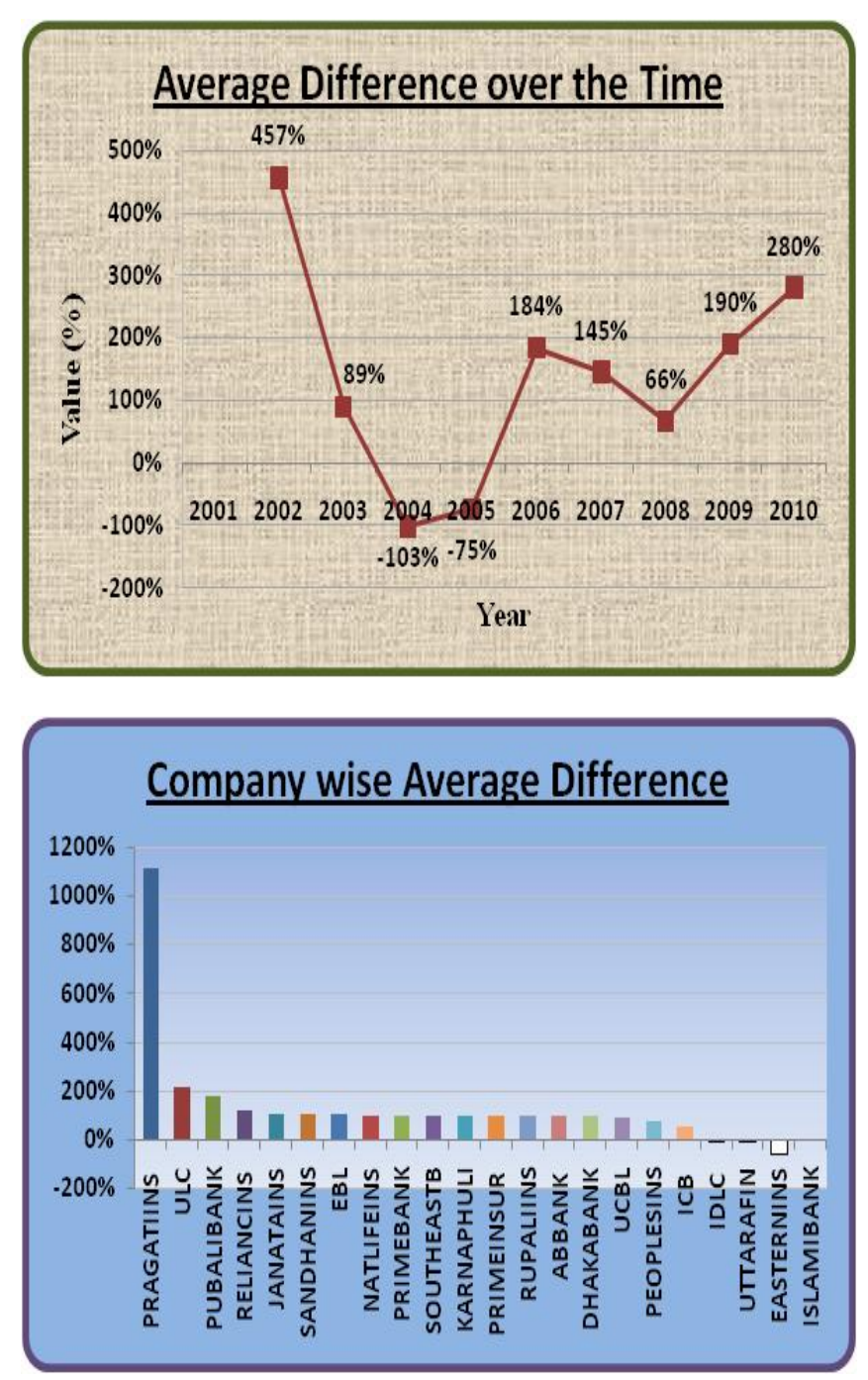

Figure 13. Repayment of Borrowing Net Income Vs Operating Cash Flow Average Difference over Time and Company-wise

Explanation: Our study gives us evidence that most of the time traditional ratio overstate the firm's repayment capabilities that was highest in 2002 at up to $457 \%$. At the same time PRAGATIINS abnormally overstates by $1115 \%$ [Appendix 14].

Significance to Decision Making: Accurate Borrowing repayment capability helps both lender and equity investor to adopt up to date decision.

Dividend Payout from Net Income Vs Operating Cash Flow: We all know that Dividend payout ratio shows us the percentage of NI that a firm paid to its equity holders as dividend but we should compare this amount against CFFO. Because only this relationship can tells us the accurate dividend income generated from current year operation.

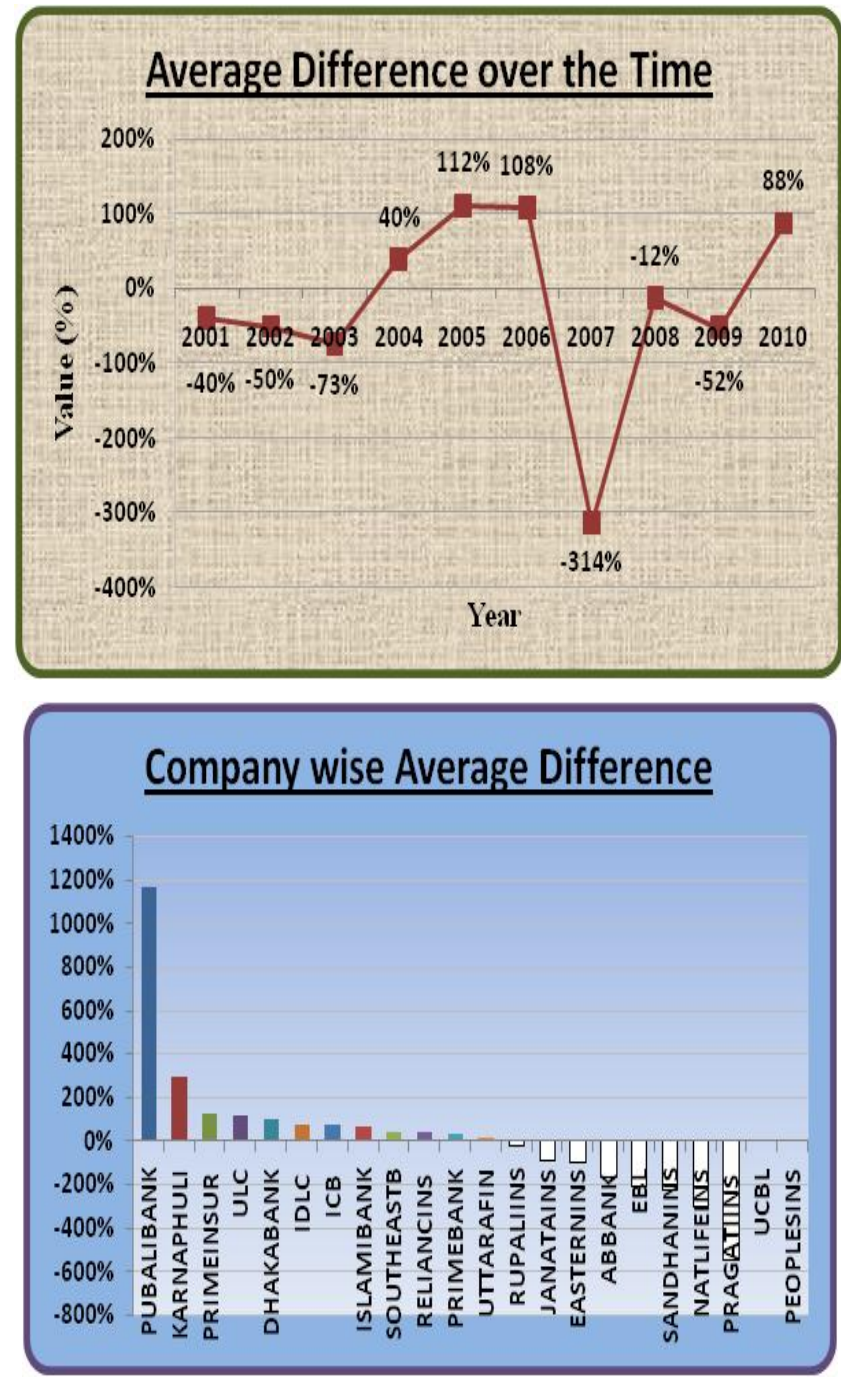

Figure 14. Dividend Payout from Net Income Vs Operating Cash Flow Average Difference over Time and Company-wise

Explanation: From our study, we invent that there is a mixed trend differences between two types of dividend payout ratio. Sometimes it overstates and sometimes understates the actual scenario. This diverse trend also exists within the company also, where PUBALIBANK overstates by $1163 \%$ and PRAGATIINS understates by $550 \%$ [Appendix 15].

Significance to Decision Making: As dividend play an important role in time of taking investment decision getting the accurate return information is also important.

Capital Employed Vs Cash to Equity Employed: Traditional capital employed gives us an idea about the amount that has been invested on long-term assets from total fund. At the same time, Cash to equity employed shows the total cash investment amount from total collected fund. 

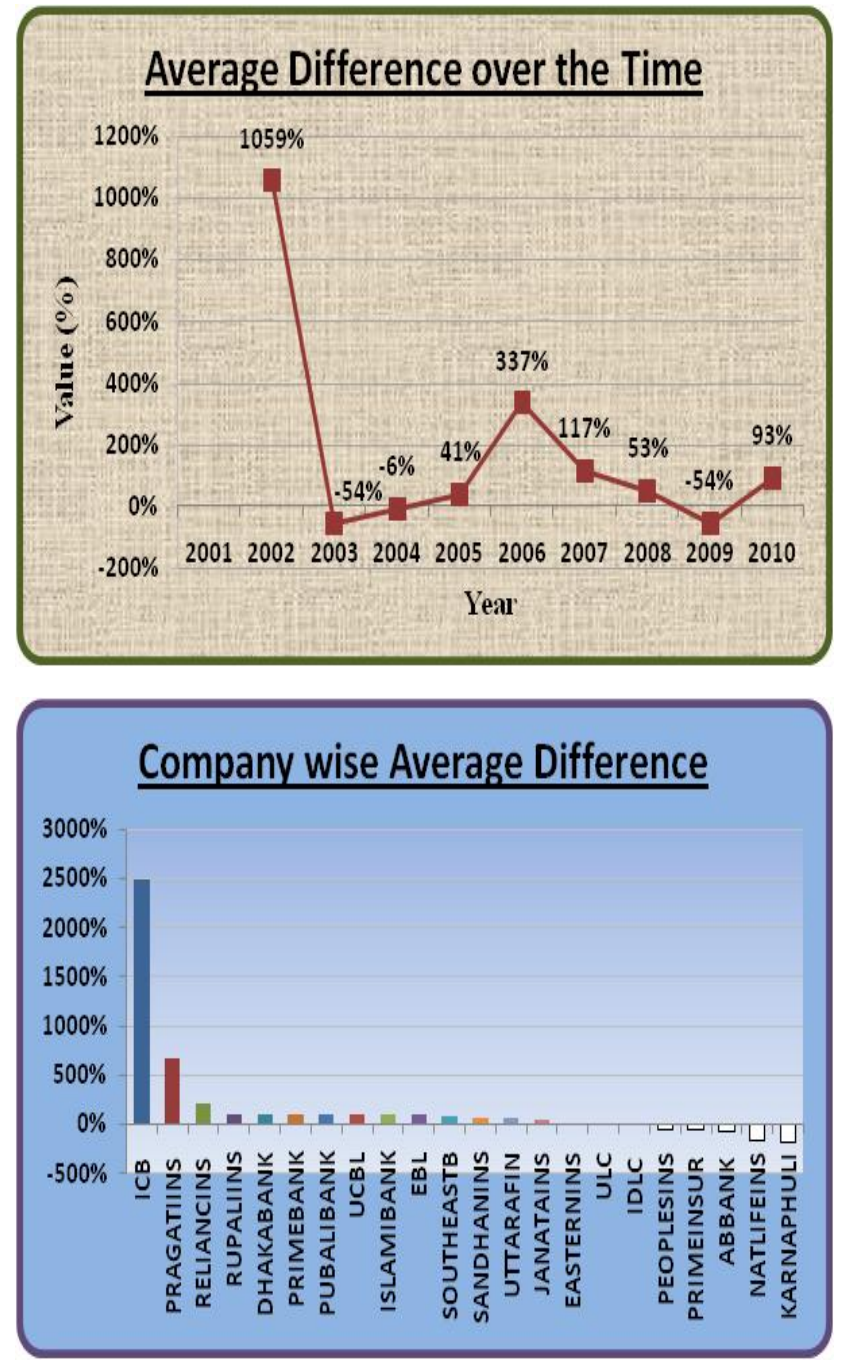

Figure 15. Capital Employed Vs Cash to Equity Employed Average Difference over Time and Company-wise

Explanation: If we notice the average difference curve then it is clear that in 2002 there was an abnormal difference. Nevertheless, from 2003 it was within normal range. On the other hand, individual company graph tells us ICB was the highest positive difference and KARNAPHULI has the height negative differences [Appendix 16].

Significance to Decision Making: Based on this modern cash to Equity employed, one can predict an organization's accurate future prospect.

\section{Recommendations}

This study does not suggest overlooking traditional balance sheet and income statement ratios. Cash flow ratios and traditional ratios could be used to optimum advantage of an entity as these ratios complement each other. The cash flow statement can also be useful to identify manipulation of cash. By comparing the components of operating cash flow, it will give further insight on the relationship between liquidity and financial distress.

Since the introduction of the cash flow statement in financial reporting additional data has been made available. This reinforces the need for further research with the inclusion of cash flow data or the combination of cash flow data in accrual ratios. This study has proposed that cash flow ratios be used in conjunction with traditional ratios.

There are some other developed ratios that can be used for further study on these issues. The ratios are:

$$
\begin{aligned}
& \text { - } \text { Quality of sales }=\frac{\text { Cash from Sales }}{\text { Sales }} \\
& \text { - } \text { Quality of Income }=\frac{\text { CFFO }}{\text { Opearting Income }} \\
& \text { - Cash Sources Component Percentages }= \\
& \frac{\text { Cash from Financing Activities }}{\text { Total Sources of Cash }}
\end{aligned}
$$

- Financing Policies Ratio $=$

$$
\frac{\text { Cash from Financing Activities }}{\text { Total Assets }}
$$

- Capital Expenditure Ratio =

$$
\frac{\text { Capital Expenditure Ratio }=}{\text { CFFO }}
$$

The suggested following ratios should provide a starting point for further analysis and give a foundation for common usage.

\section{Conclusions}

After an evaluation of entities by means of selected cash flow ratios, it was found that cash flow information has explanatory power. The ratios that are suggested in this study, if used in conjunction with traditional balance sheet and income statement that will lead to a better indication of the financial strength and weaknesses of an entity. It also has the potential to serve as an early warning of financial distress and bankruptcy. 


\section{Appendices}

Appendix 01

\begin{tabular}{|c|c|c|c|c|c|c|c|c|c|c|c|c|}
\hline \multicolumn{13}{|c|}{ Current Ratio Vs Cash to Short Term Debt } \\
\hline Company Year & & 2001 & 2002 & 2003 & 2004 & 2005 & 2006 & 2007 & 2008 & 2009 & 2010 & Average \\
\hline$\overline{\mathrm{EBL}}$ & Differences (\%) & $99 \%$ & $126 \%$ & $215 \%$ & $89 \%$ & $94 \%$ & $86 \%$ & $99 \%$ & $40 \%$ & $117 \%$ & $116 \%$ & $108 \%$ \\
\hline JANATAINS & Differences (\%) & $104 \%$ & $99 \%$ & $102 \%$ & $94 \%$ & $104 \%$ & $102 \%$ & $93 \%$ & 99\% & $98 \%$ & $98 \%$ & $99 \%$ \\
\hline IDLC & Differences (\%) & $56 \%$ & $51 \%$ & $96 \%$ & $91 \%$ & $130 \%$ & $134 \%$ & $126 \%$ & $117 \%$ & $96 \%$ & 91\% & $99 \%$ \\
\hline $\mathrm{ICB}$ & Differences (\%) & $105 \%$ & $81 \%$ & $99 \%$ & 97\% & $99 \%$ & $112 \%$ & $93 \%$ & $96 \%$ & $96 \%$ & $102 \%$ & $98 \%$ \\
\hline KARNAPHULI & Differences (\%) & $104 \%$ & $97 \%$ & $94 \%$ & $98 \%$ & $101 \%$ & $100 \%$ & $95 \%$ & $97 \%$ & $97 \%$ & $94 \%$ & $98 \%$ \\
\hline PUBALIBANK & Differences (\%) & $99 \%$ & $107 \%$ & $88 \%$ & $89 \%$ & $100 \%$ & $148 \%$ & $78 \%$ & $74 \%$ & $90 \%$ & $103 \%$ & $97 \%$ \\
\hline PRIMEINSUR & Differences (\%) & $91 \%$ & $91 \%$ & $97 \%$ & $99 \%$ & $103 \%$ & $101 \%$ & $94 \%$ & $100 \%$ & $93 \%$ & $97 \%$ & $97 \%$ \\
\hline EASTERNINS & Differences (\%) & $96 \%$ & $92 \%$ & $98 \%$ & $91 \%$ & $102 \%$ & $98 \%$ & $96 \%$ & $104 \%$ & $94 \%$ & $92 \%$ & $96 \%$ \\
\hline DHAKABANK & Differences (\%) & $71 \%$ & $129 \%$ & $113 \%$ & $68 \%$ & $121 \%$ & $71 \%$ & $63 \%$ & $121 \%$ & $89 \%$ & $117 \%$ & $96 \%$ \\
\hline ULC & Differences (\%) & $24 \%$ & $44 \%$ & $111 \%$ & $130 \%$ & $114 \%$ & $122 \%$ & $119 \%$ & $102 \%$ & $90 \%$ & $97 \%$ & $95 \%$ \\
\hline RUPALIINS & Differences (\%) & $97 \%$ & $95 \%$ & $88 \%$ & $92 \%$ & $90 \%$ & $92 \%$ & $87 \%$ & $84 \%$ & $89 \%$ & $84 \%$ & $90 \%$ \\
\hline PRIMEBANK & Differences (\%) & $71 \%$ & $96 \%$ & $89 \%$ & $82 \%$ & $104 \%$ & $57 \%$ & $86 \%$ & $71 \%$ & $86 \%$ & $156 \%$ & $90 \%$ \\
\hline PRAGATIINS & Differences (\%) & $81 \%$ & $99 \%$ & $82 \%$ & $73 \%$ & $95 \%$ & $75 \%$ & $99 \%$ & $83 \%$ & $96 \%$ & $95 \%$ & $88 \%$ \\
\hline UTTARAFIN & Differences (\%) & $56 \%$ & $86 \%$ & $96 \%$ & $92 \%$ & $93 \%$ & $92 \%$ & $92 \%$ & $85 \%$ & $92 \%$ & $93 \%$ & $88 \%$ \\
\hline RELIANCINS & Differences (\%) & $80 \%$ & $75 \%$ & $99 \%$ & $84 \%$ & $101 \%$ & $82 \%$ & $76 \%$ & $78 \%$ & $83 \%$ & $92 \%$ & $85 \%$ \\
\hline ISLAMIBANK & Differences (\%) & $69 \%$ & $74 \%$ & $82 \%$ & $84 \%$ & $91 \%$ & $80 \%$ & $144 \%$ & $55 \%$ & $74 \%$ & $92 \%$ & $85 \%$ \\
\hline UCBL & Differences (\%) & $73 \%$ & $65 \%$ & $84 \%$ & $73 \%$ & $130 \%$ & $95 \%$ & $96 \%$ & $34 \%$ & $66 \%$ & $85 \%$ & $80 \%$ \\
\hline ABBANK & Differences (\%) & $99 \%$ & $86 \%$ & $114 \%$ & $39 \%$ & $251 \%$ & $-4 \%$ & $19 \%$ & $58 \%$ & $17 \%$ & $88 \%$ & $77 \%$ \\
\hline PEOPLESINS & Differences (\%) & $59 \%$ & $77 \%$ & $59 \%$ & $101 \%$ & $38 \%$ & $61 \%$ & $69 \%$ & $120 \%$ & $86 \%$ & $84 \%$ & $75 \%$ \\
\hline NATLIFEINS & Differences (\%) & $61 \%$ & $66 \%$ & $68 \%$ & $67 \%$ & $66 \%$ & $68 \%$ & $72 \%$ & $76 \%$ & $74 \%$ & $72 \%$ & $69 \%$ \\
\hline SANDHANINS & Differences (\%) & $63 \%$ & $73 \%$ & $70 \%$ & $63 \%$ & $56 \%$ & $59 \%$ & $57 \%$ & $68 \%$ & $75 \%$ & $76 \%$ & $66 \%$ \\
\hline SOUTHEASTB & Differences (\%) & $85 \%$ & $87 \%$ & $66 \%$ & $39 \%$ & $162 \%$ & $107 \%$ & $20 \%$ & $27 \%$ & $-61 \%$ & $122 \%$ & $66 \%$ \\
\hline & Average $=$ & $79 \%$ & $86 \%$ & $96 \%$ & $83 \%$ & $107 \%$ & $88 \%$ & $85 \%$ & $81 \%$ & $79 \%$ & $97 \%$ & \\
\hline
\end{tabular}

Appendix 02

\begin{tabular}{|c|c|c|c|c|c|c|c|c|c|c|c|c|}
\hline \multicolumn{13}{|c|}{ Quick Ratio Vs Critical Needs Coverage } \\
\hline Company Year & & 2001 & 2002 & 2003 & 2004 & 2005 & 2006 & 2007 & 2008 & 2009 & 2010 & Average \\
\hline JANATAINS & Differences (\%) & $104 \%$ & $99 \%$ & $102 \%$ & $94 \%$ & $104 \%$ & $102 \%$ & $93 \%$ & $99 \%$ & $98 \%$ & $98 \%$ & $99 \%$ \\
\hline KARNAPHULI & Differences (\%) & $104 \%$ & $97 \%$ & 94\% & $98 \%$ & $101 \%$ & $100 \%$ & 95\% & $97 \%$ & $97 \%$ & $94 \%$ & $98 \%$ \\
\hline PRIMEINSUR & Differences (\%) & $92 \%$ & $92 \%$ & $98 \%$ & 99\% & $103 \%$ & $101 \%$ & 94\% & $100 \%$ & 93\% & $97 \%$ & $97 \%$ \\
\hline EASTERNINS & Differences (\%) & $96 \%$ & $92 \%$ & $98 \%$ & $92 \%$ & $102 \%$ & $98 \%$ & $96 \%$ & $104 \%$ & $94 \%$ & $92 \%$ & $96 \%$ \\
\hline ICB & Differences (\%) & $101 \%$ & $78 \%$ & 95\% & $92 \%$ & $94 \%$ & $105 \%$ & $87 \%$ & 91\% & $92 \%$ & $97 \%$ & $93 \%$ \\
\hline RUPALIINS & Differences (\%) & 98\% & $95 \%$ & $89 \%$ & 93\% & $90 \%$ & 92\% & $87 \%$ & $84 \%$ & $89 \%$ & $84 \%$ & $90 \%$ \\
\hline PRAGATIINS & Differences (\%) & $82 \%$ & $99 \%$ & $82 \%$ & $74 \%$ & 95\% & $80 \%$ & 99\% & $83 \%$ & $96 \%$ & $96 \%$ & $89 \%$ \\
\hline IDLC & Differences (\%) & $49 \%$ & $46 \%$ & $84 \%$ & $80 \%$ & $115 \%$ & $117 \%$ & $108 \%$ & $100 \%$ & $89 \%$ & $85 \%$ & $87 \%$ \\
\hline UTTARAFIN & Differences (\%) & $58 \%$ & $86 \%$ & $96 \%$ & $92 \%$ & $93 \%$ & $92 \%$ & $92 \%$ & $86 \%$ & $84 \%$ & $86 \%$ & $86 \%$ \\
\hline ULC & Differences (\%) & $23 \%$ & $42 \%$ & $98 \%$ & $118 \%$ & $102 \%$ & $107 \%$ & $107 \%$ & $88 \%$ & $85 \%$ & $91 \%$ & $86 \%$ \\
\hline RELIANCINS & Differences (\%) & $82 \%$ & $77 \%$ & 99\% & $84 \%$ & $101 \%$ & $83 \%$ & $77 \%$ & $78 \%$ & $83 \%$ & $92 \%$ & $86 \%$ \\
\hline ISLAMIBANK & Differences (\%) & $70 \%$ & $74 \%$ & $82 \%$ & $84 \%$ & 91\% & $80 \%$ & $144 \%$ & $55 \%$ & $74 \%$ & $92 \%$ & $85 \%$ \\
\hline PUBALIBANK & Differences (\%) & $80 \%$ & $87 \%$ & 72\% & $76 \%$ & $85 \%$ & $121 \%$ & $55 \%$ & $49 \%$ & $60 \%$ & $70 \%$ & $75 \%$ \\
\hline EBL & Differences (\%) & $85 \%$ & $104 \%$ & $176 \%$ & $59 \%$ & $61 \%$ & $23 \%$ & $46 \%$ & $0 \%$ & $89 \%$ & $69 \%$ & $71 \%$ \\
\hline NATLIFEINS & Differences (\%) & $61 \%$ & $66 \%$ & $68 \%$ & $68 \%$ & $66 \%$ & $68 \%$ & $72 \%$ & $76 \%$ & $74 \%$ & $72 \%$ & $69 \%$ \\
\hline SANDHANINS & Differences (\%) & $63 \%$ & $73 \%$ & $70 \%$ & $63 \%$ & $56 \%$ & $59 \%$ & $57 \%$ & $68 \%$ & $75 \%$ & $76 \%$ & $66 \%$ \\
\hline DHAKABANK & Differences (\%) & $58 \%$ & $101 \%$ & $87 \%$ & $51 \%$ & $77 \%$ & $33 \%$ & $27 \%$ & $82 \%$ & $54 \%$ & $84 \%$ & $65 \%$ \\
\hline UCBL & Differences (\%) & 57\% & $44 \%$ & $62 \%$ & $56 \%$ & $101 \%$ & $59 \%$ & $38 \%$ & $-4 \%$ & $34 \%$ & $41 \%$ & $49 \%$ \\
\hline PRIMEBANK & Differences (\%) & $52 \%$ & $73 \%$ & $58 \%$ & $53 \%$ & $60 \%$ & $8 \%$ & $24 \%$ & $16 \%$ & $26 \%$ & $95 \%$ & $47 \%$ \\
\hline ABBANK & Differences (\%) & $78 \%$ & $63 \%$ & $81 \%$ & $8 \%$ & $191 \%$ & $-50 \%$ & $-29 \%$ & $-5 \%$ & $-46 \%$ & $36 \%$ & $33 \%$ \\
\hline SOUTHEASTB & Differences (\%) & $52 \%$ & $46 \%$ & $21 \%$ & $17 \%$ & $81 \%$ & $-7 \%$ & $-59 \%$ & $-84 \%$ & $-151 \%$ & $45 \%$ & $-4 \%$ \\
\hline PEOPLESINS & Differences (\%) & $-106 \%$ & $-36 \%$ & $-171 \%$ & $113 \%$ & \begin{tabular}{|l|}
$-679 \%$ \\
\end{tabular} & $-369 \%$ & $-101 \%$ & $197 \%$ & $50 \%$ & $54 \%$ & $-105 \%$ \\
\hline & Average $=$ & $65 \%$ & $73 \%$ & $75 \%$ & $76 \%$ & $59 \%$ & $50 \%$ & $60 \%$ & $66 \%$ & $61 \%$ & $79 \%$ & \\
\hline
\end{tabular}




\begin{tabular}{|c|c|c|c|c|c|c|c|c|c|c|c|c|}
\hline \multicolumn{13}{|c|}{ Fixed Assets Turnover Vs Cash to Fixed Assets } \\
\hline Company Year & & 2001 & 2002 & 2003 & 2004 & 2005 & 2006 & 2007 & 2008 & 2009 & 2010 & Average \\
\hline EBL & Differences (\%) & $98 \%$ & $176 \%$ & $340 \%$ & $80 \%$ & $89 \%$ & $84 \%$ & $99 \%$ & $13 \%$ & $128 \%$ & $120 \%$ & $123 \%$ \\
\hline ULC & Differences (\%) & $10 \%$ & $12 \%$ & $154 \%$ & $276 \%$ & $156 \%$ & $186 \%$ & $188 \%$ & $107 \%$ & $26 \%$ & $75 \%$ & $119 \%$ \\
\hline IDLC & Differences (\%) & $27 \%$ & $26 \%$ & $82 \%$ & $61 \%$ & $232 \%$ & $250 \%$ & $213 \%$ & $172 \%$ & $65 \%$ & $23 \%$ & $115 \%$ \\
\hline PUBALIBANK & Differences (\%) & $96 \%$ & $123 \%$ & $56 \%$ & $57 \%$ & $99 \%$ & $174 \%$ & $67 \%$ & $57 \%$ & $85 \%$ & $103 \%$ & $92 \%$ \\
\hline DHAKABANK & Differences (\%) & $-33 \%$ & $183 \%$ & $135 \%$ & $-11 \%$ & $129 \%$ & $59 \%$ & $36 \%$ & $134 \%$ & $80 \%$ & $131 \%$ & $84 \%$ \\
\hline PRIMEBANK & Differences (\%) & $14 \%$ & $89 \%$ & $80 \%$ & $66 \%$ & $106 \%$ & $45 \%$ & $85 \%$ & $70 \%$ & $86 \%$ & $149 \%$ & $79 \%$ \\
\hline ABBANK & Differences (\%) & $97 \%$ & $61 \%$ & $132 \%$ & $-30 \%$ & $291 \%$ & $-56 \%$ & $-3 \%$ & $57 \%$ & $23 \%$ & $87 \%$ & $66 \%$ \\
\hline JANATAINS & Differences (\%) & $326 \%$ & $24 \%$ & $219 \%$ & $-255 \%$ & $280 \%$ & $175 \%$ & $-169 \%$ & $43 \%$ & $-25 \%$ & $3 \%$ & $62 \%$ \\
\hline $\mathrm{ICB}$ & Differences (\%) & $226 \%$ & $-366 \%$ & $85 \%$ & $48 \%$ & $72 \%$ & $309 \%$ & $-1 \%$ & $47 \%$ & $44 \%$ & $137 \%$ & $60 \%$ \\
\hline SOUTHEASTB & Differences (\%) & $73 \%$ & $80 \%$ & $49 \%$ & $-69 \%$ & $156 \%$ & $105 \%$ & $37 \%$ & $57 \%$ & $-21 \%$ & $122 \%$ & $59 \%$ \\
\hline $\mathrm{UCBL}$ & Differences (\%) & $15 \%$ & $7 \%$ & $62 \%$ & $19 \%$ & $153 \%$ & $93 \%$ & $96 \%$ & $6 \%$ & $40 \%$ & $81 \%$ & $57 \%$ \\
\hline ISLAMIBANK & Differences (\%) & $2 \%$ & $9 \%$ & $40 \%$ & $57 \%$ & 77\% & $55 \%$ & $164 \%$ & $16 \%$ & $46 \%$ & $86 \%$ & $55 \%$ \\
\hline UTTARAFIN & Differences (\%) & $38 \%$ & $87 \%$ & $77 \%$ & $51 \%$ & $62 \%$ & $53 \%$ & $54 \%$ & $20 \%$ & $54 \%$ & $41 \%$ & $54 \%$ \\
\hline PEOPLESINS & Differences (\%) & $9 \%$ & $48 \%$ & $19 \%$ & $103 \%$ & $-16 \%$ & $45 \%$ & $50 \%$ & $129 \%$ & $82 \%$ & $63 \%$ & $53 \%$ \\
\hline EASTERNINS & Differences (\%) & $22 \%$ & $-34 \%$ & $69 \%$ & $-40 \%$ & $124 \%$ & $67 \%$ & $42 \%$ & $144 \%$ & $18 \%$ & $-4 \%$ & $41 \%$ \\
\hline PRIMEINSUR & Differences (\%) & $-111 \%$ & $-91 \%$ & $35 \%$ & 72\% & 197\% & $144 \%$ & $-49 \%$ & $93 \%$ & $-67 \%$ & $37 \%$ & $26 \%$ \\
\hline KARNAPHULI & Differences (\%) & $241 \%$ & $-25 \%$ & $-104 \%$ & $1 \%$ & $160 \%$ & $136 \%$ & $-236 \%$ & $-51 \%$ & $28 \%$ & $-88 \%$ & $6 \%$ \\
\hline RUPALIINS & Differences (\%) & 51\% & $1 \%$ & $-132 \%$ & $-59 \%$ & $-108 \%$ & $-44 \%$ & $-127 \%$ & $-172 \%$ & $-93 \%$ & $-281 \%$ & $-96 \%$ \\
\hline PRAGATIINS & Differences (\%) & $-212 \%$ & $78 \%$ & $-356 \%$ & $-635 \%$ & $-8 \%$ & $-551 \%$ & $86 \%$ & $-257 \%$ & $-13 \%$ & $-43 \%$ & $-191 \%$ \\
\hline RELIANCINS & Differences (\%) & $-230 \%$ & $-353 \%$ & $91 \%$ & $-176 \%$ & $123 \%$ & $-225 \%$ & $-445 \%$ & $-358 \%$ & $-274 \%$ & $-72 \%$ & $-192 \%$ \\
\hline NATLIFEINS & Differences (\%) & $-413 \%$ & $-375 \%$ & $-337 \%$ & $-302 \%$ & $-303 \%$ & $-247 \%$ & $-149 \%$ & $-132 \%$ & $-160 \%$ & $-212 \%$ & $-263 \%$ \\
\hline SANDHANINS & Differences (\%) & $-491 \%$ & $-366 \%$ & $-438 \%$ & $-451 \%$ & $-523 \%$ & $-341 \%$ & $-322 \%$ & $-191 \%$ & $-97 \%$ & $-92 \%$ & $-331 \%$ \\
\hline & Average $=$ & $-7 \%$ & $-28 \%$ & $16 \%$ & $-52 \%$ & $70 \%$ & $23 \%$ & $-13 \%$ & $0 \%$ & $3 \%$ & $21 \%$ & \\
\hline
\end{tabular}

Appendix 04

\begin{tabular}{|c|c|c|c|c|c|c|c|c|c|c|c|c|}
\hline \multicolumn{13}{|c|}{ Total Assets Turnover Vs Reinvestment } \\
\hline Company Year & & 2001 & 2002 & 2003 & 2004 & 2005 & 2006 & 2007 & 2008 & 2009 & 2010 & Average \\
\hline ULC & Differences (\%) & $-127 \%$ & $-169 \%$ & $54457 \%$ & $475248 \%$ & $67373 \%$ & $31384 \%$ & $103671 \%$ & $2553 \%$ & $-56262 \%$ & $-2155 \%$ & $67597 \%$ \\
\hline EBL & Differences (\%) & $-1646 \%$ & $233465 \%$ & $33188 \%$ & $-3363 \%$ & $-1028 \%$ & $-3968 \%$ & $-84 \%$ & $-10346 \%$ & 30054\% & $8355 \%$ & $28463 \%$ \\
\hline PRIMEINSUR & Differences (\%) & $-24737 \%$ & $-27609 \%$ & $-14028 \%$ & $-3129 \%$ & $75300 \%$ & $308178 \%$ & $-24813 \%$ & $-1347 \%$ & $-62592 \%$ & $-5644 \%$ & $21958 \%$ \\
\hline IDLC & Differences (\%) & $-159 \%$ & $-164 \%$ & $36 \%$ & $-65 \%$ & $9655 \%$ & $29581 \%$ & $44093 \%$ & $27417 \%$ & $-8499 \%$ & $-12066 \%$ & $8983 \%$ \\
\hline PEOPLESINS & Differences (\%) & $-694 \%$ & $-369 \%$ & $-407 \%$ & $115 \%$ & $-503 \%$ & $-5598 \%$ & $-4420 \%$ & $6397 \%$ & $-10107 \%$ & $-4038 \%$ & $-1962 \%$ \\
\hline UTTARAFIN & Differences (\%) & $-157 \%$ & $46 \%$ & $-93 \%$ & $-160 \%$ & $-206 \%$ & $-64 \%$ & $-157 \%$ & $-725 \%$ & $-4947 \%$ & $-29975 \%$ & $-3644 \%$ \\
\hline PRIMEBANK & Differences (\%) & & & $-5966 \%$ & $-10636 \%$ & $2336 \%$ & $-32930 \%$ & $-3530 \%$ & $-5895 \%$ & $-5018 \%$ & $25047 \%$ & $-4574 \%$ \\
\hline DHAKABANK & Differences (\%) & \begin{tabular}{|l|}
$-137344 \%$ \\
\end{tabular} & $18592 \%$ & & $-69993 \%$ & 193333\% & $-18159 \%$ & $-36177 \%$ & $16961 \%$ & $-15317 \%$ & $4460 \%$ & $-4849 \%$ \\
\hline SOUTHEASTB & Differences (\%) & $-10682 \%$ & $-20031 \%$ & $-4562 \%$ & $-38661 \%$ & $16390 \%$ & $556 \%$ & $-27987 \%$ & $-7764 \%$ & $-19994 \%$ & $11371 \%$ & $-10136 \%$ \\
\hline ABBANK & Differences (\%) & $-3437 \%$ & $-36776 \%$ & $77669 \%$ & $-281927 \%$ & $257148 \%$ & $-9475 \%$ & $-4906 \%$ & $-19856 \%$ & $-91218 \%$ & $-1435 \%$ & $-11421 \%$ \\
\hline $\mathrm{UCBL}$ & Differences (\%) & $-32243 \%$ & $-19529 \%$ & $-18817 \%$ & $-46273 \%$ & $30451 \%$ & $-4123 \%$ & $-933 \%$ & $-9252 \%$ & $-13644 \%$ & $-2938 \%$ & $-11730 \%$ \\
\hline RUPALIINS & Differences (\%) & $-14162 \%$ & $-16411 \%$ & $-26923 \%$ & $-35210 \%$ & $-10604 \%$ & $-14136 \%$ & $-7179 \%$ & $-11293 \%$ & $-11127 \%$ & $-37010 \%$ & $-18405 \%$ \\
\hline ISLAMIBANK & Differences (\%) & $-21795 \%$ & $-52188 \%$ & $-26012 \%$ & $-22196 \%$ & $-16664 \%$ & $-16931 \%$ & $28140 \%$ & $-30855 \%$ & $-46336 \%$ & $-8199 \%$ & $-21304 \%$ \\
\hline SANDHANINS & Differences (\%) & $-4589 \%$ & $-24306 \%$ & $-12867 \%$ & $-46098 \%$ & $-17923 \%$ & $-6631 \%$ & $-75391 \%$ & $-42912 \%$ & \begin{tabular}{l|l|}
$-6037 \%$ \\
\end{tabular} & $-5736 \%$ & $-24249 \%$ \\
\hline NATLIFEINS & Differences (\%) & $-27079 \%$ & $-35490 \%$ & $-29766 \%$ & $-33186 \%$ & $-49274 \%$ & $-27459 \%$ & $-18139 \%$ & $-24572 \%$ & $-26727 \%$ & $-56541 \%$ & $-32823 \%$ \\
\hline PRAGATIINS & Differences (\%) & $-15337 \%$ & $-1345 \%$ & $-52157 \%$ & $-65205 \%$ & $-28886 \%$ & $-60846 \%$ & $-3385 \%$ & $-86345 \%$ & $-27766 \%$ & $-46815 \%$ & $-38809 \%$ \\
\hline KARNAPHULI & Differences (\%) & $75983 \%$ & $-26278 \%$ & $-83549 \%$ & $-137954 \%$ & $101082 \%$ & 71459\% & $-275990 \%$ & $-170032 \%$ & $-124903 \%$ & $-9286 \%$ & $-57947 \%$ \\
\hline RELIANCINS & Differences (\%) & \begin{tabular}{|l|}
$-114486 \%$ \\
\end{tabular} & $-5261 \%$ & $-857 \%$ & $-35320 \%$ & $3352 \%$ & $-59674 \%$ & $-334163 \%$ & $-93609 \%$ & $-27146 \%$ & $-1896 \%$ & $-66906 \%$ \\
\hline $\mathrm{ICB}$ & Differences (\%) & $357326 \%$ & $-617521 \%$ & $-66278 \%$ & $-443322 \%$ & $-48687 \%$ & $190679 \%$ & $-140216 \%$ & $-32084 \%$ & $-50435 \%$ & $44043 \%$ & $-80649 \%$ \\
\hline JANATAINS & Differences (\%) & $65163 \%$ & $-77408 \%$ & $114201 \%$ & $-197257 \%$ & $303951 \%$ & $37696 \%$ & $-1208814 \%$ & $-54416 \%$ & $-14425 \%$ & $-63504 \%$ & $-109481 \%$ \\
\hline EASTERNINS & Differences (\%) & \begin{tabular}{|l|}
$-133950 \%$ \\
\end{tabular} & $-84877 \%$ & $-11000 \%$ & $-478150 \%$ & $312 \%$ & $-16260 \%$ & $-67334 \%$ & $42883 \%$ & $-183395 \%$ & $-165600 \%$ & $-109737 \%$ \\
\hline PUBALIBANK & Differences (\%) & $-14331 \%$ & $38273 \%$ & $-4661716 \%$ & $-197912 \%$ & $-50254 \%$ & $196985 \%$ & & $-241923 \%$ & $-11185 \%$ & $3922 \%$ & $-548682 \%$ \\
\hline & Average $=$ & $-2785 \%$ & $-35969 \%$ & $25497 \%$ & $-75939 \%$ & $38030 \%$ & $26830 \%$ & $-97986 \%$ & $-33955 \%$ & $-35774 \%$ & $-16165 \%$ & \\
\hline
\end{tabular}


Appendix 05

\begin{tabular}{|c|c|c|c|c|c|c|c|c|c|c|c|c|}
\hline \multicolumn{13}{|c|}{ Debt to Assets Vs Cash to Debt } \\
\hline Company Year & & 2001 & 2002 & 2003 & 2004 & 2005 & 2006 & 2007 & 2008 & 2009 & 2010 & Average \\
\hline$\overline{E B L}$ & Differences (\%) & $100 \%$ & $110 \%$ & $134 \%$ & $98 \%$ & $99 \%$ & $\mathbf{9 8 \%}$ & $100 \%$ & $88 \%$ & $104 \%$ & $103 \%$ & $103 \%$ \\
\hline PUBALIBANK & Differences (\%) & $100 \%$ & $101 \%$ & $98 \%$ & $98 \%$ & $100 \%$ & $106 \%$ & $97 \%$ & $96 \%$ & $99 \%$ & $100 \%$ & $99 \%$ \\
\hline DHAKABANK & Differences (\%) & $89 \%$ & $109 \%$ & $103 \%$ & $91 \%$ & $103 \%$ & $96 \%$ & $93 \%$ & $104 \%$ & $98 \%$ & $103 \%$ & $99 \%$ \\
\hline IDLC & Differences (\%) & $73 \%$ & $72 \%$ & $97 \%$ & $95 \%$ & $118 \%$ & $119 \%$ & $116 \%$ & $111 \%$ & $95 \%$ & $88 \%$ & $98 \%$ \\
\hline JANATAINS & Differences (\%) & $107 \%$ & $\mathbf{9 8 \%}$ & $103 \%$ & $91 \%$ & $107 \%$ & $104 \%$ & $86 \%$ & $97 \%$ & $95 \%$ & $95 \%$ & $98 \%$ \\
\hline PRIMEBANK & Differences (\%) & $91 \%$ & $99 \%$ & $98 \%$ & $97 \%$ & $101 \%$ & $95 \%$ & $98 \%$ & $97 \%$ & $99 \%$ & $105 \%$ & $98 \%$ \\
\hline $\mathrm{ICB}$ & Differences $(\%)$ & $105 \%$ & $79 \%$ & 99\% & $97 \%$ & $99 \%$ & $113 \%$ & $92 \%$ & $95 \%$ & $95 \%$ & $103 \%$ & $98 \%$ \\
\hline ABBANK & Differences (\%) & $100 \%$ & $\mathbf{9 8 \%}$ & $102 \%$ & $91 \%$ & $114 \%$ & $88 \%$ & $90 \%$ & $96 \%$ & $92 \%$ & $99 \%$ & $97 \%$ \\
\hline UCBL & Differences (\%) & $94 \%$ & $94 \%$ & $97 \%$ & $94 \%$ & $105 \%$ & $99 \%$ & $100 \%$ & $90 \%$ & $95 \%$ & $98 \%$ & $97 \%$ \\
\hline ISLAMIBANK & Differences (\%) & $92 \%$ & $93 \%$ & $95 \%$ & $97 \%$ & $98 \%$ & $96 \%$ & $105 \%$ & $92 \%$ & $95 \%$ & $99 \%$ & $96 \%$ \\
\hline SOUTHEASTB & Differences (\%) & $97 \%$ & $98 \%$ & $95 \%$ & $87 \%$ & $105 \%$ & $101 \%$ & $92 \%$ & $95 \%$ & $88 \%$ & $102 \%$ & $96 \%$ \\
\hline ULC & Differences (\%) & $47 \%$ & $62 \%$ & $107 \%$ & $122 \%$ & $109 \%$ & $113 \%$ & $112 \%$ & $101 \%$ & $87 \%$ & $95 \%$ & $96 \%$ \\
\hline UTTARAFIN & Differences (\%) & $77 \%$ & $95 \%$ & $97 \%$ & $94 \%$ & $95 \%$ & $94 \%$ & $93 \%$ & $88 \%$ & $93 \%$ & $92 \%$ & $92 \%$ \\
\hline PRIMEINSUR & Differences (\%) & $76 \%$ & $78 \%$ & $93 \%$ & $98 \%$ & $106 \%$ & $103 \%$ & $86 \%$ & $99 \%$ & $81 \%$ & $91 \%$ & $91 \%$ \\
\hline KARNAPHULI & Differences (\%) & $107 \%$ & $96 \%$ & $88 \%$ & $96 \%$ & $102 \%$ & $101 \%$ & $90 \%$ & $94 \%$ & $90 \%$ & $45 \%$ & $91 \%$ \\
\hline EASTERNINS & Differences (\%) & $93 \%$ & $86 \%$ & $97 \%$ & $82 \%$ & $104 \%$ & $94 \%$ & $89 \%$ & $122 \%$ & $59 \%$ & $51 \%$ & $88 \%$ \\
\hline NATLIFEINS & Differences (\%) & $71 \%$ & $73 \%$ & $74 \%$ & $75 \%$ & $75 \%$ & $77 \%$ & $81 \%$ & $83 \%$ & $81 \%$ & $80 \%$ & $77 \%$ \\
\hline SANDHANINS & Differences (\%) & $71 \%$ & $77 \%$ & $75 \%$ & $74 \%$ & $71 \%$ & $74 \%$ & $74 \%$ & $79 \%$ & $87 \%$ & $88 \%$ & $77 \%$ \\
\hline PEOPLESINS & Differences (\%) & $37 \%$ & $70 \%$ & $60 \%$ & $101 \%$ & $69 \%$ & $87 \%$ & $73 \%$ & $121 \%$ & $81 \%$ & $18 \%$ & $72 \%$ \\
\hline RUPALIINS & Differences (\%) & $93 \%$ & $86 \%$ & $67 \%$ & $77 \%$ & $70 \%$ & $75 \%$ & $64 \%$ & $55 \%$ & $51 \%$ & $27 \%$ & $66 \%$ \\
\hline RELIANCINS & Differences (\%) & $42 \%$ & $43 \%$ & 99\% & $59 \%$ & $103 \%$ & $54 \%$ & $37 \%$ & $43 \%$ & $50 \%$ & $80 \%$ & $61 \%$ \\
\hline \multirow[t]{2}{*}{$\overline{\text { PRAGATIINS }}$} & Differences (\%) & $55 \%$ & $97 \%$ & $55 \%$ & $28 \%$ & $86 \%$ & $6 \%$ & $95 \%$ & $-4 \%$ & $83 \%$ & $81 \%$ & $58 \%$ \\
\hline & Average $=$ & $83 \%$ & $87 \%$ & $92 \%$ & $88 \%$ & $97 \%$ & $91 \%$ & $89 \%$ & $88 \%$ & $86 \%$ & $84 \%$ & \\
\hline
\end{tabular}

Appendix 06

\begin{tabular}{|c|c|c|c|c|c|c|c|c|c|c|c|c|}
\hline \multicolumn{13}{|c|}{ Interest Coverage Vs Cash Interest Coverage } \\
\hline Company Year & & 2001 & 2002 & 2003 & 2004 & 2005 & 2006 & 2007 & 2008 & 2009 & 2010 & Average \\
\hline EBL & Differences (\%) & $98 \%$ & $174 \%$ & $312 \%$ & $82 \%$ & $91 \%$ & $86 \%$ & $99 \%$ & $18 \%$ & $134 \%$ & $116 \%$ & $121 \%$ \\
\hline IDLC & Differences (\%) & $-69 \%$ & $-86 \%$ & $83 \%$ & $63 \%$ & $259 \%$ & $274 \%$ & $213 \%$ & $165 \%$ & $69 \%$ & $37 \%$ & $101 \%$ \\
\hline UTTARAFIN & Differences (\%) & $100 \%$ & $100 \%$ & $100 \%$ & $100 \%$ & $100 \%$ & $100 \%$ & $100 \%$ & $100 \%$ & $60 \%$ & $56 \%$ & $92 \%$ \\
\hline PUBALIBANK & Differences (\%) & $95 \%$ & $123 \%$ & $45 \%$ & $37 \%$ & 99\% & $189 \%$ & $62 \%$ & $51 \%$ & $83 \%$ & $103 \%$ & $89 \%$ \\
\hline DHAKABANK & Differences (\%) & $-26 \%$ & $181 \%$ & $135 \%$ & $-9 \%$ & $134 \%$ & $47 \%$ & $35 \%$ & $139 \%$ & $80 \%$ & $132 \%$ & $85 \%$ \\
\hline ULC & Differences (\%) & $-228 \%$ & $-142 \%$ & $144 \%$ & $254 \%$ & $166 \%$ & $209 \%$ & $220 \%$ & $109 \%$ & $0 \%$ & $76 \%$ & $81 \%$ \\
\hline PRIMEBANK & Differences (\%) & $25 \%$ & $90 \%$ & $80 \%$ & $66 \%$ & $106 \%$ & $47 \%$ & $86 \%$ & $64 \%$ & $86 \%$ & $153 \%$ & $80 \%$ \\
\hline ABBANK & Differences (\%) & $98 \%$ & $49 \%$ & $140 \%$ & $-54 \%$ & $319 \%$ & $-60 \%$ & $18 \%$ & $64 \%$ & $38 \%$ & $90 \%$ & $70 \%$ \\
\hline $\mathrm{ICB}$ & Differences (\%) & $207 \%$ & $-296 \%$ & $90 \%$ & $67 \%$ & $82 \%$ & $233 \%$ & $20 \%$ & $70 \%$ & $66 \%$ & $114 \%$ & $65 \%$ \\
\hline SOUTHEASTB & Differences (\%) & $73 \%$ & $84 \%$ & $51 \%$ & $-70 \%$ & $156 \%$ & $104 \%$ & $45 \%$ & $58 \%$ & $0 \%$ & $117 \%$ & $62 \%$ \\
\hline $\mathrm{UCBL}$ & Differences (\%) & $-18 \%$ & $-26 \%$ & $56 \%$ & $12 \%$ & $160 \%$ & $93 \%$ & $96 \%$ & $-4 \%$ & $29 \%$ & $81 \%$ & $48 \%$ \\
\hline ISLAMIBANK & Differences (\%) & $-24 \%$ & $-6 \%$ & $22 \%$ & $50 \%$ & $76 \%$ & $54 \%$ & $171 \%$ & $11 \%$ & $41 \%$ & $85 \%$ & $48 \%$ \\
\hline EASTERNINS & Differences (\%) & & & & & & & & & & & \\
\hline JANATAINS & Differences (\%) & & & & & & & & & & & \\
\hline KARNAPHULI & Differences (\%) & & & & & & & & & & & \\
\hline NATLIFEINS & Differences (\%) & & & & & & & & & & & \\
\hline PEOPLESINS & Differences (\%) & & & & & & & & & & & \\
\hline PRAGATIINS & Differences (\%) & & & & & & & & & & & \\
\hline PRIMEINSUR & Differences (\%) & & & & & & & & & & & \\
\hline RELIANCINS & Differences (\%) & & & & & & & & & & & \\
\hline RUPALIINS & Differences $(\%)$ & & & & & & & & & & & \\
\hline SANDHANINS & Differences (\%) & & & & & & & & & & & \\
\hline & Average $=$ & $28 \%$ & $20 \%$ & $105 \%$ & $50 \%$ & $146 \%$ & $115 \%$ & $97 \%$ & $70 \%$ & $57 \%$ & $97 \%$ & \\
\hline
\end{tabular}


Appendix 07

\begin{tabular}{|c|c|c|c|c|c|c|c|c|c|c|c|c|}
\hline \multicolumn{13}{|c|}{ Fixed Charge Coverage Vs Cash Fixed Charge Coverage } \\
\hline Company Year & & 2001 & 2002 & 2003 & 2004 & 2005 & 2006 & 2007 & 2008 & 2009 & 2010 & Average \\
\hline ICB & Differences (\%) & $215931 \%$ & $-46279 \%$ & $159 \%$ & $276 \%$ & $1070 \%$ & $-1032 \%$ & $-1136 \%$ & $-248 \%$ & $-171 \%$ & $230 \%$ & $16880 \%$ \\
\hline IDLC & Differences (\%) & $-495 \%$ & $-495 \%$ & $40 \%$ & $-55 \%$ & $610 \%$ & $932 \%$ & $736 \%$ & $412 \%$ & $36 \%$ & $-14 \%$ & $171 \%$ \\
\hline EBL & Differences (\%) & 95\% & $263 \%$ & $537 \%$ & $64 \%$ & 79\% & $67 \%$ & 98\% & $-92 \%$ & $176 \%$ & $129 \%$ & $142 \%$ \\
\hline ULC & Differences (\%) & $-449 \%$ & $-406 \%$ & $199 \%$ & $381 \%$ & $231 \%$ & $473 \%$ & $493 \%$ & $135 \%$ & $-285 \%$ & $22 \%$ & $79 \%$ \\
\hline PUBALIBANK & Differences (\%) & $91 \%$ & $140 \%$ & $-11 \%$ & $-56 \%$ & $98 \%$ & $261 \%$ & $40 \%$ & $16 \%$ & $68 \%$ & $106 \%$ & $75 \%$ \\
\hline DHAKABANK & Differences (\%) & $-271 \%$ & $349 \%$ & $219 \%$ & $-198 \%$ & $192 \%$ & $-48 \%$ & $-80 \%$ & $196 \%$ & $47 \%$ & $159 \%$ & $57 \%$ \\
\hline PRIMEBANK & Differences (\%) & $-58 \%$ & $77 \%$ & $57 \%$ & $21 \%$ & $113 \%$ & $-35 \%$ & $66 \%$ & $30 \%$ & $71 \%$ & $198 \%$ & $54 \%$ \\
\hline UCBL & Differences (\%) & $-102 \%$ & $-147 \%$ & $21 \%$ & $-63 \%$ & $206 \%$ & $84 \%$ & $92 \%$ & $-121 \%$ & $-33 \%$ & $63 \%$ & $0 \%$ \\
\hline SOUTHEASTB & Differences (\%) & $20 \%$ & $34 \%$ & $-70 \%$ & $-383 \%$ & $235 \%$ & $112 \%$ & $-37 \%$ & $-7 \%$ & $-135 \%$ & $134 \%$ & $-10 \%$ \\
\hline ISLAMIBANK & Differences (\%) & $-180 \%$ & $-159 \%$ & $-84 \%$ & $-11 \%$ & $34 \%$ & $-53 \%$ & $280 \%$ & $-107 \%$ & $-48 \%$ & $63 \%$ & $-27 \%$ \\
\hline UTTARAFIN & Differences (\%) & $-203 \%$ & $27 \%$ & $40 \%$ & $-44 \%$ & $22 \%$ & $-12 \%$ & $-68 \%$ & $-84 \%$ & $-28 \%$ & $-52 \%$ & $-40 \%$ \\
\hline ABBANK & Differences (\%) & $93 \%$ & $-600 \%$ & $530 \%$ & $-639 \%$ & $673 \%$ & $-640 \%$ & $-63 \%$ & $26 \%$ & $-20 \%$ & $83 \%$ & $-56 \%$ \\
\hline EASTERNINS & Differences (\%) & & & & & & & & & & & \\
\hline JANATAINS & Differences (\%) & & & & & & & & & & & \\
\hline KARNAPHULI & Differences (\%) & & & & & & & & & & & \\
\hline NATLIFEINS & Differences (\%) & & & & & & & & & & & \\
\hline PEOPLESINS & Differences (\%) & & & & & & & & & & & \\
\hline PRAGATIINS & Differences (\%) & & & & & & & & & & & \\
\hline PRIMEINSUR & Differences (\%) & & & & & & & & & & & \\
\hline RELIANCINS & Differences (\%) & & & & & & & & & & & \\
\hline RUPALIINS & Differences (\%) & & & & & & & & & & & \\
\hline SANDHANINS & Differences (\%) & & & & & & & & & & & \\
\hline & Average $=$ & $17873 \%$ & $-3933 \%$ & $136 \%$ & $-59 \%$ & $297 \%$ & $9 \%$ & $35 \%$ & $13 \%$ & $-27 \%$ & $93 \%$ & \\
\hline
\end{tabular}

Appendix 08

\begin{tabular}{|c|c|c|c|c|c|c|c|c|c|c|c|c|}
\hline \multicolumn{13}{|c|}{ Return on Sales Vs Cash to Sales } \\
\hline Company Year & & 2001 & 2002 & 2003 & 2004 & 2005 & 2006 & 2007 & 2008 & 2009 & 2010 & Average \\
\hline$\overline{\mathrm{EBL}}$ & Differences (\%) & $89 \%$ & $431 \%$ & $1027 \%$ & $33 \%$ & $60 \%$ & $13 \%$ & $92 \%$ & $-473 \%$ & $220 \%$ & $155 \%$ & $165 \%$ \\
\hline JANATAINS & Differences (\%) & $733 \%$ & $67 \%$ & $143 \%$ & $-292 \%$ & $424 \%$ & $266 \%$ & $-24 \%$ & $74 \%$ & $69 \%$ & $77 \%$ & $154 \%$ \\
\hline$\overline{I D L C}$ & Differences (\%) & $-1052 \%$ & $-896 \%$ & $-12 \%$ & $-128 \%$ & $945 \%$ & $1277 \%$ & $763 \%$ & $487 \%$ & $-10 \%$ & $-78 \%$ & $130 \%$ \\
\hline KARNAPHULI & Differences (\%) & $193 \%$ & $44 \%$ & $28 \%$ & $46 \%$ & $117 \%$ & $110 \%$ & $-16 \%$ & $71 \%$ & $81 \%$ & $61 \%$ & $73 \%$ \\
\hline PRIMEINSUR & Differences (\%) & $1 \%$ & $8 \%$ & $77 \%$ & $126 \%$ & $158 \%$ & $143 \%$ & $-3 \%$ & $94 \%$ & $41 \%$ & $85 \%$ & $73 \%$ \\
\hline NATLIFEINS & Differences (\%) & $60 \%$ & $64 \%$ & $68 \%$ & $70 \%$ & $71 \%$ & $73 \%$ & $77 \%$ & $80 \%$ & $78 \%$ & $77 \%$ & $72 \%$ \\
\hline SANDHANINS & Differences (\%) & $59 \%$ & $69 \%$ & $67 \%$ & $67 \%$ & $66 \%$ & $71 \%$ & $71 \%$ & $77 \%$ & $84 \%$ & $86 \%$ & $72 \%$ \\
\hline EASTERNINS & Differences (\%) & $8 \%$ & $-8 \%$ & $78 \%$ & $26 \%$ & $114 \%$ & $75 \%$ & $67 \%$ & $131 \%$ & $60 \%$ & $63 \%$ & $61 \%$ \\
\hline DHAKABANK & Differences (\%) & $-569 \%$ & $740 \%$ & $326 \%$ & $-523 \%$ & $279 \%$ & $-203 \%$ & $-415 \%$ & $389 \%$ & $-55 \%$ & $236 \%$ & $20 \%$ \\
\hline PRAGATIINS & Differences (\%) & $-45 \%$ & $92 \%$ & $-54 \%$ & $-97 \%$ & $71 \%$ & $-47 \%$ & $97 \%$ & $20 \%$ & $68 \%$ & $69 \%$ & $18 \%$ \\
\hline ABBANK & Differences (\%) & $86 \%$ & $-2921 \%$ & $4204 \%$ & $-2853 \%$ & $2764 \%$ & $-889 \%$ & $-185 \%$ & $-38 \%$ & $-106 \%$ & $64 \%$ & $13 \%$ \\
\hline RUPALIINS & Differences (\%) & $57 \%$ & $26 \%$ & $-45 \%$ & $16 \%$ & $-9 \%$ & $32 \%$ & $-25 \%$ & $-16 \%$ & $21 \%$ & $31 \%$ & $9 \%$ \\
\hline PRIMEBANK & Differences (\%) & $-147 \%$ & $58 \%$ & $-15 \%$ & $-47 \%$ & $134 \%$ & $-173 \%$ & $22 \%$ & $-116 \%$ & $45 \%$ & $298 \%$ & $6 \%$ \\
\hline PUBALIBANK & Differences (\%) & $74 \%$ & $227 \%$ & $-406 \%$ & $-624 \%$ & $95 \%$ & $445 \%$ & $-31 \%$ & $-91 \%$ & $41 \%$ & $109 \%$ & $-16 \%$ \\
\hline ULC & Differences (\%) & $-1251 \%$ & $-1294 \%$ & $313 \%$ & $623 \%$ & $297 \%$ & $594 \%$ & $649 \%$ & $147 \%$ & $-405 \%$ & $25 \%$ & $-30 \%$ \\
\hline UTTARAFIN & Differences (\%) & $-204 \%$ & $32 \%$ & $39 \%$ & $-8 \%$ & $12 \%$ & $-35 \%$ & $-83 \%$ & $-173 \%$ & $-32 \%$ & $2 \%$ & $-45 \%$ \\
\hline RELIANCINS & Differences (\%) & $-108 \%$ & $-228 \%$ & $87 \%$ & $-122 \%$ & $118 \%$ & $-139 \%$ & $-207 \%$ & $-117 \%$ & $-89 \%$ & $51 \%$ & $-75 \%$ \\
\hline $\mathrm{ICB}$ & Differences (\%) & $819 \%$ & $-2411 \%$ & $24 \%$ & $-96 \%$ & $40 \%$ & $716 \%$ & $-246 \%$ & $37 \%$ & $26 \%$ & $127 \%$ & $-96 \%$ \\
\hline SOUTHEASTB & Differences (\%) & $-45 \%$ & $57 \%$ & $-341 \%$ & $-1225 \%$ & $631 \%$ & $127 \%$ & $-228 \%$ & $-262 \%$ & $-479 \%$ & $183 \%$ & $-158 \%$ \\
\hline ISLAMIBANK & Differences (\%) & $-766 \%$ & $-561 \%$ & $-769 \%$ & $-191 \%$ & $-68 \%$ & $-262 \%$ & $752 \%$ & $-517 \%$ & $-239 \%$ & $21 \%$ & $-260 \%$ \\
\hline UCBL & Differences (\%) & $-793 \%$ & $-1110 \%$ & $-144 \%$ & $-731 \%$ & $393 \%$ & $64 \%$ & $79 \%$ & $-608 \%$ & $-347 \%$ & $19 \%$ & $-318 \%$ \\
\hline PEOPLESINS & Differences (\%) & $-407 \%$ & $-122 \%$ & $-269 \%$ & $113 \%$ & $-313 \%$ & $159 \%$ & $-25294 \%$ & $534 \%$ & $15 \%$ & $-503 \%$ & $-2609 \%$ \\
\hline & Average $=$ & $-146 \%$ & $-347 \%$ & $201 \%$ & $-264 \%$ & $291 \%$ & $110 \%$ & $-1095 \%$ & $-12 \%$ & $-42 \%$ & $57 \%$ & \\
\hline
\end{tabular}


Appendix 09

\begin{tabular}{|c|c|c|c|c|c|c|c|c|c|c|c|c|}
\hline \multicolumn{13}{|c|}{ Return on Assets Vs Cash to Assets } \\
\hline Company Year & & 2001 & 2002 & 2003 & 2004 & 2005 & 2006 & 2007 & 2008 & 2009 & 2010 & Average \\
\hline EBL & Differences (\%) & $89 \%$ & $431 \%$ & $1027 \%$ & $33 \%$ & $60 \%$ & $13 \%$ & $92 \%$ & $-473 \%$ & $220 \%$ & $155 \%$ & $165 \%$ \\
\hline JANATAINS & Differences (\%) & $733 \%$ & $67 \%$ & $143 \%$ & $-292 \%$ & $424 \%$ & $266 \%$ & $-24 \%$ & $74 \%$ & $69 \%$ & $77 \%$ & $154 \%$ \\
\hline IDLC & Differences (\%) & $-1052 \%$ & $-896 \%$ & $-12 \%$ & $-128 \%$ & $945 \%$ & $1277 \%$ & 763\% & $487 \%$ & $-10 \%$ & $-78 \%$ & $130 \%$ \\
\hline KARNAPHULI & Differences (\%) & 193\% & $44 \%$ & $28 \%$ & $46 \%$ & $117 \%$ & $110 \%$ & $-16 \%$ & $71 \%$ & $81 \%$ & $61 \%$ & $73 \%$ \\
\hline PRIMEINSUR & Differences (\%) & $1 \%$ & $8 \%$ & 77\% & $126 \%$ & $158 \%$ & $143 \%$ & $-3 \%$ & $94 \%$ & $41 \%$ & $85 \%$ & $73 \%$ \\
\hline NATLIFEINS & Differences (\%) & $60 \%$ & $64 \%$ & $68 \%$ & $70 \%$ & 71\% & $73 \%$ & 77\% & $80 \%$ & $78 \%$ & $77 \%$ & $72 \%$ \\
\hline SANDHANINS & Differences (\%) & $59 \%$ & $69 \%$ & $67 \%$ & $67 \%$ & $66 \%$ & 71\% & 71\% & 77\% & $84 \%$ & $86 \%$ & $72 \%$ \\
\hline EASTERNINS & Differences (\%) & $8 \%$ & $-8 \%$ & $78 \%$ & $26 \%$ & $114 \%$ & $75 \%$ & $67 \%$ & $131 \%$ & $60 \%$ & $63 \%$ & $61 \%$ \\
\hline DHAKABANK & Differences (\%) & $-569 \%$ & $740 \%$ & $326 \%$ & $-523 \%$ & $279 \%$ & $-203 \%$ & $-415 \%$ & $389 \%$ & $-55 \%$ & $236 \%$ & $20 \%$ \\
\hline PRAGATIINS & Differences (\%) & $-45 \%$ & $92 \%$ & $-54 \%$ & $-97 \%$ & 71\% & $-47 \%$ & 97\% & $20 \%$ & $68 \%$ & $69 \%$ & $18 \%$ \\
\hline ABBANK & Differences (\%) & $86 \%$ & $-2921 \%$ & $4204 \%$ & $-2853 \%$ & $2764 \%$ & $-889 \%$ & $-185 \%$ & $-38 \%$ & $-106 \%$ & $64 \%$ & $13 \%$ \\
\hline RUPALIINS & Differences (\%) & $57 \%$ & $26 \%$ & $-45 \%$ & $16 \%$ & $-9 \%$ & $32 \%$ & $-25 \%$ & $-16 \%$ & $21 \%$ & $31 \%$ & $9 \%$ \\
\hline PRIMEBANK & Differences (\%) & $-147 \%$ & $58 \%$ & $-15 \%$ & $-47 \%$ & $134 \%$ & $-173 \%$ & $22 \%$ & $-116 \%$ & $45 \%$ & $298 \%$ & $6 \%$ \\
\hline PUBALIBANK & Differences (\%) & $74 \%$ & $227 \%$ & $-406 \%$ & $-624 \%$ & $95 \%$ & $445 \%$ & $-31 \%$ & $-91 \%$ & $41 \%$ & $109 \%$ & $-16 \%$ \\
\hline ULC & Differences (\%) & $-1251 \%$ & $-1294 \%$ & 313\% & $623 \%$ & $297 \%$ & $594 \%$ & 649\% & $147 \%$ & $-405 \%$ & $25 \%$ & $-30 \%$ \\
\hline UTTARAFIN & Differences (\%) & $-204 \%$ & $32 \%$ & 39\% & $-8 \%$ & $12 \%$ & $-35 \%$ & $-83 \%$ & $-173 \%$ & $-32 \%$ & $2 \%$ & $-45 \%$ \\
\hline RELIANCINS & Differences (\%) & $-108 \%$ & $-228 \%$ & $87 \%$ & $-122 \%$ & $118 \%$ & $-139 \%$ & $-207 \%$ & $-117 \%$ & $-89 \%$ & $51 \%$ & $-75 \%$ \\
\hline ICB & Differences (\%) & $819 \%$ & $-2411 \%$ & $24 \%$ & $-96 \%$ & $40 \%$ & 716\% & $-246 \%$ & $37 \%$ & $26 \%$ & $127 \%$ & $-96 \%$ \\
\hline SOUTHEASTB & Differences (\%) & $-45 \%$ & $57 \%$ & $-341 \%$ & $-1225 \%$ & $631 \%$ & $127 \%$ & $-228 \%$ & $-262 \%$ & $-479 \%$ & $183 \%$ & $-158 \%$ \\
\hline ISLAMIBANK & Differences (\%) & $-766 \%$ & $-561 \%$ & $-769 \%$ & $-191 \%$ & $-68 \%$ & $-262 \%$ & $752 \%$ & $-517 \%$ & $-239 \%$ & $21 \%$ & $-260 \%$ \\
\hline UCBL & Differences (\%) & $-793 \%$ & $-1110 \%$ & $-144 \%$ & $-731 \%$ & $393 \%$ & $64 \%$ & 79\% & $-608 \%$ & $-347 \%$ & $19 \%$ & $-318 \%$ \\
\hline PEOPLESINS & Differences (\%) & $-407 \%$ & $-122 \%$ & $-269 \%$ & $113 \%$ & $-313 \%$ & $159 \%$ & $-25294 \%$ & $534 \%$ & $15 \%$ & $-503 \%$ & $-2609 \%$ \\
\hline & Average $=$ & $-146 \%$ & $-347 \%$ & $201 \%$ & $-264 \%$ & $291 \%$ & $110 \%$ & $-1095 \%$ & $-12 \%$ & $-42 \%$ & $57 \%$ & \\
\hline
\end{tabular}

Appendix 10

\begin{tabular}{|c|c|c|c|c|c|c|c|c|c|c|c|c|}
\hline \multicolumn{13}{|c|}{ Return on Equity Vs Cash to Equity } \\
\hline Company Year & & 2001 & 2002 & 2003 & 2004 & 2005 & 2006 & 2007 & 2008 & 2009 & 2010 & Average \\
\hline $\mathrm{EBL}$ & Differences (\%) & $89 \%$ & $431 \%$ & $1027 \%$ & $33 \%$ & $60 \%$ & $13 \%$ & $92 \%$ & $-473 \%$ & $220 \%$ & $155 \%$ & $165 \%$ \\
\hline JANATAINS & Differences (\%) & $733 \%$ & $67 \%$ & $143 \%$ & $-292 \%$ & $424 \%$ & $266 \%$ & $-24 \%$ & $74 \%$ & $69 \%$ & $77 \%$ & $154 \%$ \\
\hline IDLC & Differences (\%) & $-1052 \%$ & $-896 \%$ & $-12 \%$ & $-128 \%$ & $945 \%$ & $1277 \%$ & $763 \%$ & $487 \%$ & $-10 \%$ & $-78 \%$ & $130 \%$ \\
\hline KARNAPHULI & Differences (\%) & $193 \%$ & $44 \%$ & $28 \%$ & $46 \%$ & $117 \%$ & $110 \%$ & $-16 \%$ & $71 \%$ & $81 \%$ & $61 \%$ & $73 \%$ \\
\hline PRIMEINSUR & Differences (\%) & $1 \%$ & $8 \%$ & $77 \%$ & $126 \%$ & $158 \%$ & $143 \%$ & $-3 \%$ & $94 \%$ & $41 \%$ & $85 \%$ & $73 \%$ \\
\hline NATLIFEINS & Differences (\%) & $60 \%$ & $64 \%$ & $68 \%$ & 70\% & 71\% & $73 \%$ & $77 \%$ & $80 \%$ & $78 \%$ & $77 \%$ & $72 \%$ \\
\hline SANDHANINS & Differences (\%) & $59 \%$ & $69 \%$ & $67 \%$ & $67 \%$ & $66 \%$ & $71 \%$ & $71 \%$ & $77 \%$ & $84 \%$ & $86 \%$ & $72 \%$ \\
\hline EASTERNINS & Differences (\%) & $8 \%$ & $-8 \%$ & $78 \%$ & $26 \%$ & $114 \%$ & $75 \%$ & $67 \%$ & $131 \%$ & $60 \%$ & $63 \%$ & $61 \%$ \\
\hline DHAKABANK & Differences (\%) & $-569 \%$ & $740 \%$ & $326 \%$ & $-523 \%$ & $279 \%$ & $-203 \%$ & $-415 \%$ & $389 \%$ & $-55 \%$ & $236 \%$ & $20 \%$ \\
\hline PRAGATIINS & Differences (\%) & $-45 \%$ & $92 \%$ & $-54 \%$ & $-97 \%$ & $71 \%$ & $-47 \%$ & $97 \%$ & $20 \%$ & $68 \%$ & $69 \%$ & $18 \%$ \\
\hline ABBANK & Differences (\%) & $86 \%$ & $-2921 \%$ & $4204 \%$ & $-2853 \%$ & $2764 \%$ & $-889 \%$ & $-185 \%$ & $-38 \%$ & $-106 \%$ & $64 \%$ & $13 \%$ \\
\hline RUPALIINS & Differences (\%) & $57 \%$ & $26 \%$ & $-45 \%$ & $16 \%$ & $-9 \%$ & $32 \%$ & $-25 \%$ & $-16 \%$ & $21 \%$ & $31 \%$ & $9 \%$ \\
\hline PRIMEBANK & Differences (\%) & $-147 \%$ & $58 \%$ & $-15 \%$ & $-47 \%$ & $134 \%$ & $-173 \%$ & $22 \%$ & $-116 \%$ & $45 \%$ & $298 \%$ & $6 \%$ \\
\hline PUBALIBANK & Differences (\%) & $74 \%$ & $227 \%$ & $-406 \%$ & $-624 \%$ & $95 \%$ & $445 \%$ & $-31 \%$ & $-91 \%$ & $41 \%$ & $109 \%$ & $-16 \%$ \\
\hline ULC & Differences (\%) & $-1251 \%$ & $-1294 \%$ & $313 \%$ & $623 \%$ & $297 \%$ & $594 \%$ & $649 \%$ & $147 \%$ & $-405 \%$ & $25 \%$ & $-30 \%$ \\
\hline UTTARAFIN & Differences (\%) & $-204 \%$ & $32 \%$ & $39 \%$ & $-8 \%$ & $12 \%$ & $-35 \%$ & $-83 \%$ & $-173 \%$ & $-32 \%$ & $2 \%$ & $-45 \%$ \\
\hline RELIANCINS & Differences (\%) & $-108 \%$ & $-228 \%$ & $87 \%$ & $-122 \%$ & $118 \%$ & $-139 \%$ & $-207 \%$ & $-117 \%$ & $-89 \%$ & $51 \%$ & $-75 \%$ \\
\hline ICB & Differences (\%) & $819 \%$ & $-2411 \%$ & $24 \%$ & $-96 \%$ & $40 \%$ & $716 \%$ & $-246 \%$ & $37 \%$ & $26 \%$ & $127 \%$ & $-96 \%$ \\
\hline SOUTHEASTB & Differences (\%) & $-45 \%$ & $57 \%$ & $-341 \%$ & $-1225 \%$ & $631 \%$ & $127 \%$ & $-228 \%$ & $-262 \%$ & $-479 \%$ & $183 \%$ & $-158 \%$ \\
\hline ISLAMIBANK & Differences (\%) & $-766 \%$ & $-561 \%$ & $-769 \%$ & $-191 \%$ & $-68 \%$ & $-262 \%$ & $752 \%$ & $-517 \%$ & $-239 \%$ & $21 \%$ & $-260 \%$ \\
\hline UCBL & Differences (\%) & $-793 \%$ & $-1110 \%$ & $-144 \%$ & $-731 \%$ & $393 \%$ & $64 \%$ & $79 \%$ & $-608 \%$ & $-347 \%$ & $19 \%$ & $-318 \%$ \\
\hline PEOPLESINS & Differences (\%) & $-407 \%$ & $-122 \%$ & $-269 \%$ & $113 \%$ & $-313 \%$ & $159 \%$ & $-25294 \%$ & $534 \%$ & $15 \%$ & $-503 \%$ & $-2609 \%$ \\
\hline & Average $=$ & $-146 \%$ & $-347 \%$ & $201 \%$ & $-264 \%$ & $291 \%$ & $110 \%$ & $-1095 \%$ & $-12 \%$ & $-42 \%$ & $57 \%$ & \\
\hline
\end{tabular}




\begin{tabular}{|c|c|c|c|c|c|c|c|c|c|c|c|c|}
\hline \multicolumn{13}{|c|}{ Capital Employed Vs Cash to Equity Employed } \\
\hline Company Year & & 2001 & 2002 & 2003 & 2004 & 2005 & 2006 & 2007 & 2008 & 2009 & 2010 & Average \\
\hline EBL & Differences (\%) & $89 \%$ & $431 \%$ & $1027 \%$ & $33 \%$ & $60 \%$ & $13 \%$ & $92 \%$ & $-473 \%$ & $220 \%$ & $155 \%$ & $165 \%$ \\
\hline JANATAINS & Differences (\%) & $733 \%$ & $67 \%$ & $143 \%$ & $-292 \%$ & $424 \%$ & $266 \%$ & $-24 \%$ & 74\% & $69 \%$ & $77 \%$ & $154 \%$ \\
\hline IDLC & Differences (\%) & $-1052 \%$ & $-896 \%$ & $-12 \%$ & $-128 \%$ & 945\% & $1277 \%$ & $763 \%$ & $487 \%$ & $-10 \%$ & $-78 \%$ & $130 \%$ \\
\hline KARNAPHULI & Differences (\%) & $193 \%$ & $44 \%$ & $28 \%$ & $46 \%$ & $117 \%$ & $110 \%$ & $-16 \%$ & 71\% & $81 \%$ & $61 \%$ & $73 \%$ \\
\hline PRIMEINSUR & Differences (\%) & $1 \%$ & $8 \%$ & $77 \%$ & $126 \%$ & $158 \%$ & $143 \%$ & $-3 \%$ & $94 \%$ & $41 \%$ & $85 \%$ & $73 \%$ \\
\hline NATLIFEINS & Differences (\%) & $60 \%$ & $64 \%$ & $68 \%$ & $70 \%$ & $71 \%$ & $73 \%$ & $77 \%$ & $80 \%$ & $78 \%$ & $77 \%$ & $72 \%$ \\
\hline SANDHANINS & Differences (\%) & $59 \%$ & $69 \%$ & $67 \%$ & $67 \%$ & $66 \%$ & $71 \%$ & $71 \%$ & $77 \%$ & $84 \%$ & $86 \%$ & $72 \%$ \\
\hline EASTERNINS & Differences (\%) & $8 \%$ & $-8 \%$ & $78 \%$ & $26 \%$ & $114 \%$ & $75 \%$ & $67 \%$ & $131 \%$ & $60 \%$ & $63 \%$ & $61 \%$ \\
\hline DHAKABANK & Differences (\%) & $-569 \%$ & $740 \%$ & $326 \%$ & $-523 \%$ & $279 \%$ & $-203 \%$ & $-415 \%$ & $389 \%$ & $-55 \%$ & $236 \%$ & $20 \%$ \\
\hline PRAGATIINS & Differences (\%) & $-45 \%$ & $92 \%$ & $-54 \%$ & $-97 \%$ & $71 \%$ & $-47 \%$ & $97 \%$ & $20 \%$ & $68 \%$ & $69 \%$ & $18 \%$ \\
\hline ABBANK & Differences (\%) & $86 \%$ & $-2921 \%$ & $4204 \%$ & $-2853 \%$ & $2764 \%$ & $-889 \%$ & $-185 \%$ & $-38 \%$ & $-106 \%$ & $64 \%$ & $13 \%$ \\
\hline RUPALIINS & Differences (\%) & $57 \%$ & $26 \%$ & $-45 \%$ & $16 \%$ & $-9 \%$ & $32 \%$ & $-25 \%$ & $-16 \%$ & $21 \%$ & $31 \%$ & $9 \%$ \\
\hline PRIMEBANK & Differences (\%) & $-147 \%$ & $58 \%$ & $-15 \%$ & $-47 \%$ & $134 \%$ & $-173 \%$ & $22 \%$ & $-116 \%$ & $45 \%$ & $298 \%$ & $6 \%$ \\
\hline PUBALIBANK & Differences (\%) & $74 \%$ & $227 \%$ & $-406 \%$ & $-624 \%$ & $95 \%$ & $445 \%$ & $-31 \%$ & $-91 \%$ & $41 \%$ & $109 \%$ & $-16 \%$ \\
\hline ULC & Differences (\%) & $-1251 \%$ & $-1294 \%$ & $313 \%$ & $623 \%$ & $297 \%$ & $594 \%$ & $649 \%$ & $147 \%$ & $-405 \%$ & $25 \%$ & $-30 \%$ \\
\hline UTTARAFIN & Differences (\%) & $-204 \%$ & $32 \%$ & $39 \%$ & $-8 \%$ & $12 \%$ & $-35 \%$ & $-83 \%$ & $-173 \%$ & $-32 \%$ & $2 \%$ & $-45 \%$ \\
\hline RELIANCINS & Differences (\%) & $-108 \%$ & $-228 \%$ & $87 \%$ & $-122 \%$ & $118 \%$ & $-139 \%$ & $-207 \%$ & $-117 \%$ & $-89 \%$ & $51 \%$ & $-75 \%$ \\
\hline ICB & Differences (\%) & $819 \%$ & $-2411 \%$ & $24 \%$ & $-96 \%$ & $40 \%$ & $716 \%$ & $-246 \%$ & $37 \%$ & $26 \%$ & $127 \%$ & $-96 \%$ \\
\hline SOUTHEASTB & Differences (\%) & $-45 \%$ & $57 \%$ & $-341 \%$ & $-1225 \%$ & $631 \%$ & $127 \%$ & $-228 \%$ & $-262 \%$ & $-479 \%$ & $183 \%$ & $-158 \%$ \\
\hline ISLAMIBANK & Differences (\%) & $-766 \%$ & $-561 \%$ & $-769 \%$ & $-191 \%$ & $-68 \%$ & $-262 \%$ & $752 \%$ & $-517 \%$ & $-239 \%$ & $21 \%$ & $-260 \%$ \\
\hline UCBL & Differences (\%) & $-793 \%$ & $-1110 \%$ & $-144 \%$ & $-731 \%$ & $393 \%$ & $64 \%$ & $79 \%$ & $-608 \%$ & $-347 \%$ & $19 \%$ & $-318 \%$ \\
\hline PEOPLESINS & Differences (\%) & $-407 \%$ & $-122 \%$ & $-269 \%$ & $113 \%$ & $-313 \%$ & $159 \%$ & $-25294 \%$ & $534 \%$ & $15 \%$ & $-503 \%$ & $-2609 \%$ \\
\hline & Average $=$ & $-146 \%$ & $-347 \%$ & $201 \%$ & $-264 \%$ & $291 \%$ & $110 \%$ & $-1095 \%$ & $-12 \%$ & $-42 \%$ & $57 \%$ & \\
\hline
\end{tabular}

Appendix 12

\begin{tabular}{|c|c|c|c|c|c|c|c|c|c|c|c|c|}
\hline \multicolumn{13}{|c|}{ Debt Coverage Vs Debt Coverage } \\
\hline Company Year & & 2001 & 2002 & 2003 & 2004 & 2005 & 2006 & 2007 & 2008 & 2009 & 2010 & Average \\
\hline PEOPLESINS & Differences (\%) & $80 \%$ & $55 \%$ & $73 \%$ & $847 \%$ & $76 \%$ & $268 \%$ & $100 \%$ & $123 \%$ & $-17 \%$ & $83 \%$ & $169 \%$ \\
\hline ULC & Differences (\%) & $93 \%$ & $93 \%$ & $147 \%$ & $119 \%$ & $151 \%$ & $120 \%$ & $118 \%$ & $313 \%$ & $80 \%$ & $-32 \%$ & $120 \%$ \\
\hline SOUTHEASTB & Differences (\%) & $31 \%$ & $-131 \%$ & $77 \%$ & $92 \%$ & $119 \%$ & $477 \%$ & $69 \%$ & 72\% & $83 \%$ & $221 \%$ & $111 \%$ \\
\hline DHAKABANK & Differences (\%) & $85 \%$ & $116 \%$ & $144 \%$ & $84 \%$ & $156 \%$ & $67 \%$ & $81 \%$ & $135 \%$ & $36 \%$ & $173 \%$ & $108 \%$ \\
\hline KARNAPHULI & Differences (\%) & $208 \%$ & $-79 \%$ & $-39 \%$ & $-84 \%$ & 692\% & $1061 \%$ & $14 \%$ & $-239 \%$ & $-415 \%$ & $-157 \%$ & $96 \%$ \\
\hline UCBL & Differences (\%) & $98 \%$ & 99\% & $92 \%$ & $99 \%$ & $103 \%$ & $77 \%$ & $55 \%$ & \begin{tabular}{l|l|}
$99 \%$ \\
\end{tabular} & $98 \%$ & $91 \%$ & $91 \%$ \\
\hline IDLC & Differences (\%) & 91\% & $90 \%$ & $10 \%$ & $56 \%$ & $112 \%$ & $108 \%$ & $115 \%$ & $126 \%$ & $9 \%$ & $44 \%$ & $76 \%$ \\
\hline ICB & Differences (\%) & $114 \%$ & $96 \%$ & $-32 \%$ & $49 \%$ & $-66 \%$ & $116 \%$ & $71 \%$ & $-59 \%$ & $-36 \%$ & $468 \%$ & $72 \%$ \\
\hline ISLAMIBANK & Differences (\%) & $88 \%$ & $85 \%$ & $88 \%$ & $66 \%$ & $41 \%$ & 72\% & $115 \%$ & $84 \%$ & $70 \%$ & $-27 \%$ & $68 \%$ \\
\hline PRIMEBANK & Differences (\%) & $59 \%$ & $-140 \%$ & $13 \%$ & $32 \%$ & $392 \%$ & $63 \%$ & $-28 \%$ & $54 \%$ & $-82 \%$ & $151 \%$ & $51 \%$ \\
\hline RELIANCINS & Differences (\%) & $52 \%$ & $69 \%$ & $-669 \%$ & $55 \%$ & $655 \%$ & $58 \%$ & $67 \%$ & $54 \%$ & $47 \%$ & $-102 \%$ & $29 \%$ \\
\hline UTTARAFIN & Differences (\%) & $67 \%$ & $-48 \%$ & $-64 \%$ & $8 \%$ & $-14 \%$ & $26 \%$ & $45 \%$ & $63 \%$ & $24 \%$ & $-2 \%$ & $11 \%$ \\
\hline EASTERNINS & Differences (\%) & $-9 \%$ & $8 \%$ & $-349 \%$ & $-35 \%$ & $802 \%$ & $-307 \%$ & $-200 \%$ & $423 \%$ & $-150 \%$ & $-170 \%$ & $1 \%$ \\
\hline ABBANK & Differences (\%) & $-623 \%$ & $97 \%$ & $102 \%$ & $97 \%$ & $104 \%$ & $90 \%$ & $65 \%$ & $28 \%$ & $52 \%$ & $-178 \%$ & $-17 \%$ \\
\hline JANATAINS & Differences (\%) & $116 \%$ & $-207 \%$ & $333 \%$ & $74 \%$ & $131 \%$ & $160 \%$ & $19 \%$ & $-292 \%$ & $-222 \%$ & $-334 \%$ & $-22 \%$ \\
\hline RUPALIINS & Differences (\%) & $-132 \%$ & $-36 \%$ & $31 \%$ & $-19 \%$ & $8 \%$ & $-46 \%$ & $20 \%$ & $14 \%$ & $-26 \%$ & $-46 \%$ & $-23 \%$ \\
\hline PUBALIBANK & Differences (\%) & $-286 \%$ & $179 \%$ & $80 \%$ & $86 \%$ & $-1759 \%$ & $129 \%$ & $24 \%$ & $48 \%$ & $-69 \%$ & $1163 \%$ & $-40 \%$ \\
\hline EBL & Differences (\%) & $-787 \%$ & $130 \%$ & $111 \%$ & $-50 \%$ & $-149 \%$ & $-15 \%$ & $-1200 \%$ & $83 \%$ & $183 \%$ & $283 \%$ & $-141 \%$ \\
\hline PRIMEINSUR & Differences (\%) & $-1 \%$ & $-9 \%$ & $-332 \%$ & $480 \%$ & $271 \%$ & $335 \%$ & $3 \%$ & $-1639 \%$ & $-69 \%$ & $-584 \%$ & $-154 \%$ \\
\hline NATLIFEINS & Differences (\%) & $-151 \%$ & $-174 \%$ & $-213 \%$ & $-238 \%$ & $-246 \%$ & $-265 \%$ & $-339 \%$ & $-403 \%$ & $-361 \%$ & $-343 \%$ & $-273 \%$ \\
\hline SANDHANINS & Differences (\%) & $-146 \%$ & $-222 \%$ & $-207 \%$ & $-207 \%$ & $-193 \%$ & $-244 \%$ & $-245 \%$ & $-338 \%$ & $-533 \%$ & $-593 \%$ & $-293 \%$ \\
\hline PRAGATIINS & Differences (\%) & $31 \%$ & $-1144 \%$ & $35 \%$ & $49 \%$ & $-247 \%$ & $32 \%$ & $-3269 \%$ & $-25 \%$ & $-211 \%$ & $-228 \%$ & $-498 \%$ \\
\hline & Average $=$ & $-42 \%$ & $-49 \%$ & $-26 \%$ & $76 \%$ & $52 \%$ & $108 \%$ & $-195 \%$ & $-58 \%$ & $-69 \%$ & $-5 \%$ & \\
\hline
\end{tabular}


Appendix 13

\begin{tabular}{|c|c|c|c|c|c|c|c|c|c|c|c|c|}
\hline \multicolumn{13}{|c|}{ Repayment of Borrowing Vs Repayment of Borrowing } \\
\hline Company Year & & 2001 & 2002 & 2003 & 2004 & 2005 & 2006 & 2007 & 2008 & 2009 & 2010 & Average \\
\hline PRAGATIINS & Differences (\%) & & $7540 \%$ & $154 \%$ & $484 \%$ & $566 \%$ & $292 \%$ & $659 \%$ & $112 \%$ & $100 \%$ & $131 \%$ & $1115 \%$ \\
\hline$\overline{\mathrm{ULC}}$ & Differences (\%) & & $110 \%$ & $31 \%$ & $60 \%$ & $4 \%$ & $124 \%$ & $85 \%$ & $-307 \%$ & $68 \%$ & $1759 \%$ & $215 \%$ \\
\hline PUBALIBANK & Differences (\%) & & $179 \%$ & $100 \%$ & $100 \%$ & $100 \%$ & $100 \%$ & $100 \%$ & $100 \%$ & 736\% & $76 \%$ & $177 \%$ \\
\hline RELIANCINS & Differences (\%) & & $100 \%$ & $100 \%$ & $100 \%$ & $100 \%$ & $100 \%$ & $100 \%$ & $100 \%$ & $100 \%$ & $248 \%$ & $116 \%$ \\
\hline JANATAINS & Differences (\%) & & $100 \%$ & $100 \%$ & $100 \%$ & $100 \%$ & $100 \%$ & $100 \%$ & $100 \%$ & $100 \%$ & $139 \%$ & $104 \%$ \\
\hline SANDHANINS & Differences (\%) & & $100 \%$ & $100 \%$ & $100 \%$ & $101 \%$ & $116 \%$ & $102 \%$ & $104 \%$ & $106 \%$ & $105 \%$ & $104 \%$ \\
\hline$\overline{E B L}$ & Differences (\%) & & $126 \%$ & $100 \%$ & $100 \%$ & $100 \%$ & $100 \%$ & $100 \%$ & $100 \%$ & $100 \%$ & $100 \%$ & $103 \%$ \\
\hline NATLIFEINS & Differences (\%) & & $102 \%$ & $102 \%$ & $103 \%$ & $100 \%$ & $100 \%$ & $100 \%$ & $100 \%$ & $100 \%$ & $100 \%$ & $101 \%$ \\
\hline PRIMEBANK & Differences (\%) & & $100 \%$ & $100 \%$ & $100 \%$ & $100 \%$ & $100 \%$ & $100 \%$ & $100 \%$ & $100 \%$ & $100 \%$ & $100 \%$ \\
\hline SOUTHEASTB & Differences (\%) & & $100 \%$ & $100 \%$ & $100 \%$ & $100 \%$ & $100 \%$ & $100 \%$ & $100 \%$ & $100 \%$ & $100 \%$ & $100 \%$ \\
\hline KARNAPHULI & Differences (\%) & & $100 \%$ & $100 \%$ & $100 \%$ & $100 \%$ & $100 \%$ & $100 \%$ & $100 \%$ & $100 \%$ & $100 \%$ & $100 \%$ \\
\hline PRIMEINSUR & Differences (\%) & & $100 \%$ & $100 \%$ & $100 \%$ & $100 \%$ & $100 \%$ & $100 \%$ & $100 \%$ & $100 \%$ & $100 \%$ & $100 \%$ \\
\hline RUPALIINS & Differences (\%) & & $100 \%$ & $100 \%$ & $100 \%$ & $100 \%$ & $100 \%$ & $100 \%$ & $100 \%$ & $100 \%$ & $100 \%$ & $100 \%$ \\
\hline ABBANK & Differences (\%) & & $97 \%$ & $100 \%$ & $100 \%$ & $100 \%$ & 99\% & $100 \%$ & $100 \%$ & $100 \%$ & $100 \%$ & $100 \%$ \\
\hline DHAKABANK & Differences (\%) & & $100 \%$ & $100 \%$ & $100 \%$ & $156 \%$ & $100 \%$ & $81 \%$ & $100 \%$ & $36 \%$ & $100 \%$ & $97 \%$ \\
\hline $\mathrm{UCBL}$ & Differences (\%) & & $92 \%$ & $105 \%$ & $129 \%$ & $103 \%$ & $105 \%$ & $124 \%$ & $86 \%$ & $100 \%$ & $-23 \%$ & $91 \%$ \\
\hline PEOPLESINS & Differences (\%) & & $100 \%$ & $100 \%$ & $100 \%$ & $70 \%$ & $-94 \%$ & $107 \%$ & $100 \%$ & $100 \%$ & $100 \%$ & $76 \%$ \\
\hline ICB & Differences (\%) & & $100 \%$ & $100 \%$ & $49 \%$ & $-66 \%$ & $100 \%$ & 71\% & $-57 \%$ & $100 \%$ & $100 \%$ & $55 \%$ \\
\hline IDLC & Differences (\%) & & $110 \%$ & $196 \%$ & $-765 \%$ & $60 \%$ & $89 \%$ & $97 \%$ & $68 \%$ & $48 \%$ & $39 \%$ & $-6 \%$ \\
\hline UTTARAFIN & Differences (\%) & & $137 \%$ & $156 \%$ & $-1522 \%$ & $225 \%$ & $205 \%$ & $326 \%$ & $287 \%$ & $16 \%$ & $81 \%$ & $-10 \%$ \\
\hline EASTERNINS & Differences (\%) & & $0 \%$ & $-267 \%$ & $-1998 \%$ & $-3899 \%$ & $1727 \%$ & $296 \%$ & $-206 \%$ & $1577 \%$ & $2231 \%$ & $-60 \%$ \\
\hline ISLAMIBANK & Differences (\%) & & & & & & & & & & & \\
\hline & Average $=$ & & $457 \%$ & $89 \%$ & $-103 \%$ & $-75 \%$ & $184 \%$ & $145 \%$ & $66 \%$ & $190 \%$ & $280 \%$ & \\
\hline
\end{tabular}

Appendix 14

\begin{tabular}{|c|c|c|c|c|c|c|c|c|c|c|c|c|}
\hline \multicolumn{13}{|c|}{ Dividend Payout Vs Dividend Payout } \\
\hline Company Year & & 2001 & 2002 & 2003 & 2004 & 2005 & 2006 & 2007 & 2008 & 2009 & 2010 & Average \\
\hline PUBALIBANK & Differences (\%) & & & & & & & & & & $1163 \%$ & $1163 \%$ \\
\hline KARNAPHULI & Differences (\%) & $208 \%$ & $-79 \%$ & $-39 \%$ & $-84 \%$ & $692 \%$ & $1061 \%$ & & & & & $293 \%$ \\
\hline PRIMEINSUR & Differences (\%) & $-1 \%$ & $-9 \%$ & $-332 \%$ & $480 \%$ & $271 \%$ & $335 \%$ & & & & & $124 \%$ \\
\hline ULC & Differences (\%) & 93\% & 93\% & $147 \%$ & $119 \%$ & $151 \%$ & $120 \%$ & $118 \%$ & $313 \%$ & $80 \%$ & $-32 \%$ & $120 \%$ \\
\hline DHAKABANK & Differences (\%) & $85 \%$ & $116 \%$ & $144 \%$ & $84 \%$ & $156 \%$ & $67 \%$ & $81 \%$ & & $36 \%$ & & $96 \%$ \\
\hline IDLC & Differences (\%) & $91 \%$ & $90 \%$ & $10 \%$ & $56 \%$ & $112 \%$ & $108 \%$ & $115 \%$ & $126 \%$ & $9 \%$ & $44 \%$ & $76 \%$ \\
\hline ICB & Differences (\%) & $114 \%$ & $96 \%$ & $-32 \%$ & $49 \%$ & $-66 \%$ & $116 \%$ & $71 \%$ & $-59 \%$ & $-36 \%$ & $468 \%$ & $72 \%$ \\
\hline ISLAMIBANK & Differences (\%) & $88 \%$ & $85 \%$ & $88 \%$ & & & & $115 \%$ & & & $-27 \%$ & $70 \%$ \\
\hline SOUTHEASTB & Differences (\%) & $31 \%$ & $-131 \%$ & $77 \%$ & $92 \%$ & & & $69 \%$ & $72 \%$ & $83 \%$ & & $42 \%$ \\
\hline RELIANCINS & Differences (\%) & $52 \%$ & $69 \%$ & $-669 \%$ & $55 \%$ & $655 \%$ & $58 \%$ & $67 \%$ & & & & $41 \%$ \\
\hline PRIMEBANK & Differences (\%) & $59 \%$ & $-140 \%$ & $13 \%$ & $32 \%$ & & & & $54 \%$ & & $151 \%$ & $28 \%$ \\
\hline UTTARAFIN & Differences (\%) & $67 \%$ & $-48 \%$ & $-64 \%$ & $8 \%$ & $-14 \%$ & $26 \%$ & $45 \%$ & $63 \%$ & $24 \%$ & & $12 \%$ \\
\hline RUPALIINS & Differences (\%) & $-132 \%$ & $-36 \%$ & $31 \%$ & $-19 \%$ & $8 \%$ & $-46 \%$ & $20 \%$ & $14 \%$ & $-26 \%$ & & $-21 \%$ \\
\hline JANATAINS & Differences (\%) & & & & & $131 \%$ & $160 \%$ & $19 \%$ & $-292 \%$ & $-222 \%$ & $-334 \%$ & $-90 \%$ \\
\hline EASTERNINS & Differences (\%) & $-9 \%$ & $8 \%$ & $-349 \%$ & $-35 \%$ & & & & & & & $-96 \%$ \\
\hline ABBANK & Differences (\%) & $-623 \%$ & $97 \%$ & & & & & & & $52 \%$ & $-178 \%$ & $-163 \%$ \\
\hline EBL & Differences (\%) & $-787 \%$ & $130 \%$ & $111 \%$ & $-50 \%$ & $-149 \%$ & $-15 \%$ & $-1200 \%$ & & & $283 \%$ & $-210 \%$ \\
\hline SANDHANINS & Differences (\%) & & & $-207 \%$ & & & $-244 \%$ & & & & & $-225 \%$ \\
\hline NATLIFEINS & Differences (\%) & & & $-213 \%$ & $-238 \%$ & $-246 \%$ & $-265 \%$ & $-339 \%$ & $-403 \%$ & $-361 \%$ & $-343 \%$ & $-301 \%$ \\
\hline PRAGATIINS & Differences (\%) & $31 \%$ & $-1144 \%$ & $35 \%$ & $49 \%$ & $-247 \%$ & $32 \%$ & $-3269 \%$ & & $-211 \%$ & $-228 \%$ & $-550 \%$ \\
\hline $\mathrm{UCBL}$ & Differences (\%) & & & & & & & & & & & \\
\hline PEOPLESINS & Differences (\%) & & & & & & & & & & & \\
\hline & Average $=$ & $-40 \%$ & $-50 \%$ & $-73 \%$ & $40 \%$ & $112 \%$ & $108 \%$ & $-314 \%$ & $-12 \%$ & $-52 \%$ & $88 \%$ & \\
\hline
\end{tabular}




\section{Appendix 15}

\begin{tabular}{|c|c|c|c|c|c|c|c|c|c|c|c|c|}
\hline & & & & 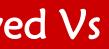 & as & 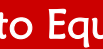 & $y$ & DC & & & & \\
\hline Company Year & & 2001 & 2002 & 2003 & 2004 & 2005 & 2006 & 2007 & 2008 & 2009 & 2010 & Average \\
\hline ICB & Differences (\%) & & $22397 \%$ & $-176 \%$ & $187 \%$ & $-67 \%$ & $108 \%$ & $205 \%$ & $-226 \%$ & $-99 \%$ & $181 \%$ & $2501 \%$ \\
\hline PRAGATIINS & Differences (\%) & & $17 \%$ & 74\% & $83 \%$ & $402 \%$ & $4988 \%$ & $108 \%$ & $-7 \%$ & $-3 \%$ & $471 \%$ & $681 \%$ \\
\hline RELIANCINS & Differences (\%) & & $-10 \%$ & $-15 \%$ & $-113 \%$ & $145 \%$ & $70 \%$ & $1834 \%$ & $-125 \%$ & $59 \%$ & $47 \%$ & $210 \%$ \\
\hline RUPALIINS & Differences (\%) & & $40 \%$ & $-58 \%$ & $81 \%$ & $140 \%$ & $260 \%$ & $28 \%$ & $17 \%$ & $94 \%$ & $352 \%$ & $106 \%$ \\
\hline DHAKABANK & Differences (\%) & & $92 \%$ & $107 \%$ & 99\% & $102 \%$ & $103 \%$ & $100 \%$ & $109 \%$ & $115 \%$ & $94 \%$ & $102 \%$ \\
\hline PRIMEBANK & Differences (\%) & & $99 \%$ & $100 \%$ & $100 \%$ & $100 \%$ & $100 \%$ & $101 \%$ & $101 \%$ & $100 \%$ & $100 \%$ & $100 \%$ \\
\hline PUBALIBANK & Differences (\%) & & \begin{tabular}{l|l|}
$99 \%$ \\
\end{tabular} & $101 \%$ & $102 \%$ & $100 \%$ & $100 \%$ & $100 \%$ & $100 \%$ & 99\% & $99 \%$ & $100 \%$ \\
\hline $\mathrm{UCBL}$ & Differences (\%) & & $107 \%$ & 97\% & 99\% & 99\% & $100 \%$ & $98 \%$ & $92 \%$ & 98\% & $96 \%$ & $98 \%$ \\
\hline ISLAMIBANK & Differences (\%) & & 99\% & $98 \%$ & 99\% & $99 \%$ & $98 \%$ & 99\% & $97 \%$ & $92 \%$ & $96 \%$ & $98 \%$ \\
\hline EBL & Differences (\%) & & $106 \%$ & 95\% & $95 \%$ & $93 \%$ & $89 \%$ & 94\% & 79\% & $100 \%$ & $96 \%$ & $94 \%$ \\
\hline SOUTHEASTB & Differences (\%) & & $90 \%$ & $90 \%$ & 93\% & $89 \%$ & $84 \%$ & 91\% & $92 \%$ & $69 \%$ & $86 \%$ & $87 \%$ \\
\hline SANDHANINS & Differences (\%) & & $180 \%$ & $76 \%$ & $24 \%$ & $6 \%$ & $22 \%$ & $45 \%$ & $90 \%$ & $77 \%$ & $56 \%$ & $64 \%$ \\
\hline UTTARAFIN & Differences (\%) & & $3 \%$ & $213 \%$ & $-98 \%$ & $-47 \%$ & $-138 \%$ & 519\% & $-34 \%$ & $154 \%$ & $-24 \%$ & $61 \%$ \\
\hline JANATAINS & Differences (\%) & & $115 \%$ & $103 \%$ & $346 \%$ & $61 \%$ & $-406 \%$ & $127 \%$ & $85 \%$ & $-21 \%$ & $29 \%$ & $49 \%$ \\
\hline EASTERNINS & Differences (\%) & & $-34 \%$ & $-5 \%$ & $42 \%$ & $48 \%$ & $1447 \%$ & $-1250 \%$ & 95\% & $-250 \%$ & $79 \%$ & $19 \%$ \\
\hline ULC & Differences (\%) & & $-313 \%$ & 99\% & $138 \%$ & $94 \%$ & $83 \%$ & $99 \%$ & $94 \%$ & $100 \%$ & $-245 \%$ & $16 \%$ \\
\hline IDLC & Differences (\%) & & $-55 \%$ & $-4 \%$ & $64 \%$ & $-54 \%$ & $0 \%$ & $40 \%$ & $-22 \%$ & $-41 \%$ & $114 \%$ & $5 \%$ \\
\hline PEOPLESINS & Differences (\%) & & $0 \%$ & $-1 \%$ & $-1 \%$ & $-14 \%$ & $154 \%$ & $14 \%$ & $137 \%$ & $-710 \%$ & $2 \%$ & $-46 \%$ \\
\hline PRIMEINSUR & Differences (\%) & & $927 \%$ & $-1045 \%$ & $26 \%$ & $-642 \%$ & $185 \%$ & $-49 \%$ & $37 \%$ & $-25 \%$ & $154 \%$ & $-48 \%$ \\
\hline ABBANK & Differences (\%) & & $101 \%$ & $90 \%$ & $-1435 \%$ & $231 \%$ & $76 \%$ & $72 \%$ & $87 \%$ & 77\% & $101 \%$ & $-67 \%$ \\
\hline NATLIFEINS & Differences (\%) & & $-725 \%$ & $-421 \%$ & $-119 \%$ & $-88 \%$ & $-180 \%$ & $-3 \%$ & $-5 \%$ & $-9 \%$ & $-3 \%$ & $-173 \%$ \\
\hline KARNAPHULI & Differences (\%) & & $-39 \%$ & $-807 \%$ & $-46 \%$ & $2 \%$ & $63 \%$ & $97 \%$ & $261 \%$ & $-1257 \%$ & $68 \%$ & $-184 \%$ \\
\hline & Average $=$ & & $1059 \%$ & $-54 \%$ & $-6 \%$ & $41 \%$ & $337 \%$ & $117 \%$ & $53 \%$ & $-54 \%$ & $93 \%$ & \\
\hline
\end{tabular}

\section{REFERENCES}

[1] Beaver, W. H. Financial ratios as predictors of failure. Journal of Accounting Research, 71-111, 1966.

[2] Blum, M. 'Failing Company Discriminant Analysis', Journal of Accounting Research, Spring, 1-25, 1974.

[3] Casey, C.J. and Bartczak, N.J. 'Cash Flow - It's Not The Bottom Line', Harvard Business Review, 61-66, 1984.

[4] Casey, C. and Bartczak, N. 'Using Operating Cash Flow Data to Predict Financial Distress: Some Extensions', Journal of Accounting Research, Vol. 23, No. 1, 384-401, 1985.

[5] Deakin, E.B. 'A Discriminant Analysis of Predictors of Business Failure', Journal of Accounting Research, 167-179, 1972.
[6] Dumbolena, I. and S. Khoury. Ratio stability and corporate failure. The Journal of Finance, Vol 35, No 4, 1017-1026, 1980.

[7] Lee, T. 'Laker Airways - The Cash Flow Truth', Accountancy, 115-116, 1982.

[8] Lee, T.A. 'Cash Flow Accounting and Corporate Financial Reporting', in Essays in British Accounting Research, M. Bromwich and A. Hopwood (eds.), Pitman Publishing Limited, London, Ch.3, 63-78, 1981.

[9] Mills J. R. and Yamamura, J.H. "The Power of Cash Flow Ratios", Journal of Accountancy, Vol.186, No.4, 53- 61, 2000.

[10] Sharma, D.S. and Iselin, E. 'The Decision Usefulness of Reported Cash Flow Information Versus Accrual Information for Banker's Assessment of Corporate Solvency', Western Decision Sciences Conference, Maui, Hawaii, 2000.

[11] Stanko BB \& Zeller TL. Cash flow ratios to measure liquidity and performance for transportation manufacturing firms. Journal of Transportation Management, Vol 2: 83-103, 1993. 